\title{
A Process-Based Assessment of CMIP5 Rainfall in the Congo Basin: The September-November Rainy Season
}

\author{
A. CREESE ${ }^{\mathrm{a}}$ AND R. WASHington \\ School of Geography and the Environment, University of Oxford, Oxford, United Kingdom
}

(Manuscript received 4 December 2017, in final form 14 May 2018)

\begin{abstract}
Congo basin September-November rainfall varies by up to a factor of 3 across CMIP5 coupled models. The severe lack of observational data in this region makes model evaluation difficult using standard techniques. This study uses a process-based assessment to evaluate the plausibility of mechanisms related to coupled model rainfall in September-November. Models tend to simulate a rainfall maximum in either the west or east of the basin. In most months, western Congo rainfall is positively correlated with eastern Congo rainfall across models, as relatively wet models are often wetter everywhere; however, in AugustNovember this correlation becomes insignificant, suggesting that processes relating to rainfall differences in each subdomain are distinct. Composite analysis of wet and dry models in each subdomain suggests that the tropical eastern Atlantic SST bias helps differentiate between models in the west: wetter models tend to have a larger $\left(\sim 1^{\circ}-2^{\circ} \mathrm{C}\right)$ and more equatorward SST bias, higher evaporation over the ocean, and higher local convection. In the east, rainfall differences between models are related to more remote SST differences, including cold South Atlantic and warm eastern Indian Ocean SSTs. Wetter models exhibit stronger westerly flow across the tropical eastern Atlantic, as part of an enhanced equatorial zonal overturning cell. Dry models in the east feature a stronger and more equatorward northerly component of the midlevel African easterly jet, which may contribute to suppressed convection over the domain. This assessment casts doubt on the credibility of models that are very wet in the west of the Congo basin and have a large Atlantic SST bias.
\end{abstract}

\section{Introduction}

The climatological importance of the Congo basin in the large-scale tropical circulation is undisputed. It is the largest hydrological catchment in Africa and supports the planet's second-largest rain forest, a vast carbon store (Williams et al. 2007; Dargie et al. 2017). As such, an understanding of the likely future climatic changes in this region is crucial. Africa as a whole is particularly vulnerable to climate change (Niang et al. 2014) and as a result has been the focus of an increasing number of scientific studies in recent years. However, while the climate systems of West Africa (e.g., Nicholson 1980; Folland et al. 1986; Cook and Vizy 2006; Pomposi et al. 2015), East Africa (e.g., Camberlin and Okoola 2003; Lyon and DeWitt 2012; Viste et al. 2013; Liebmann et al.

\footnotetext{
${ }^{a}$ ORCID: 0000-0002-2681-2555.
}

Corresponding author: Amy Creese, amy.creese@ouce.ox.ac.uk
2014; Rowell et al. 2015), and southern Africa (e.g., Reason and Mulenga 1999; Hoerling et al. 2006; Blamey and Reason 2012; Hart et al. 2013) have received increasing attention, the Congo basin has remained critically understudied (Washington et al. 2013; Creese and Washington 2016). This is due primarily to the lack of recent observational data in the Congo basin, which is one of the most data-sparse continental regions. Fewer than 10 rain gauges over the Congo basin were included in the CRU 0.5 rainfall dataset in 2010, and problems of access and political insecurity have thus far prohibited targeted observational campaigns (Washington et al. 2013). Some studies have utilized reanalysis, station data, and gridded-data products to better understand the seasonal climatology (Nicholson and Grist 2003), climate variability (Todd and Washington 2004; Sandjon et al. 2012; Balas et al. 2007; Dezfuli and Nicholson 2013; Nicholson and Dezfuli 2013; Jury et al. 2009), and dominant climate processes in the region (Jackson et al. 2009; Pokam et al. 2012, 2014). Despite this progress, 
there remains a paucity of research on climate model behavior in the Congo basin.

\section{a. Climate model evaluation in the Congo basin}

Climate model evaluation has traditionally relied upon methods of hindcast validation, whereby historical climate simulations are compared to observed data. While some studies have assessed future changes for central Africa across ensembles of coupled models (e.g., Haensler et al. 2013), our understanding of likely future changes is limited by our relatively poor understanding of the region's climatology (Washington et al. 2013, 2006). Reanalysis products can be useful proxies for observations, as they provide global coverage; however, they must be treated with some caution in areas that lack observational data, as in such cases they are mostly controlled by the reanalysis model (Washington et al. 2013). A recent comprehensive assessment of global rainfall products highlighted large discrepancies between products' interannual and decadal variability in the Congo basin (Sun et al. 2018), and previous work by the authors has shown that reanalysis, satellite, and gauge products disagree on both rainfall magnitude and location; for example, in December-February (DJF) mean rainfall in ERA-Interim reanalysis is more than double that in CMAP (satellite and gauge; Creese and Washington 2016).

Such discrepancies limit the capacity of these datasets to act as a constraint on model hindcasts (Creese and Washington 2016). Across coupled global climate models (GCMs) mean Congo basin rainfall can differ by a factor of 5 in some months. There is also little consensus between models on the location of maximum rainfall in different seasons; some models simulate a rainfall maximum exclusively in the east of the basin, some in the west (nearly $2500 \mathrm{~km}$ distant), while some exhibit patchy, disconnected regions of rainfall. Without long-term, homogenous observations, it is impossible to determine which models are able to reproduce the "real world" rainfall distribution in the Congo basin. Creese and Washington (2016) showed that use of the ensemble mean is not appropriate for GCMs in the Congo basin across all seasons, as the combination of models with distinct east and west rainfall maxima produces an ensemble mean with a rainfall distribution that is not evident in any one model.

Considering the challenges imposed by the scarcity of recent observational data on model hindcast validation in the Congo basin, this paper will instead use a regionally focused process-based assessment. This framework assesses a model's credibility depending on the mechanisms used to generate weather and climate. Such evaluations tend to focus on the capability of models to reproduce 1) the mean-state climatology (e.g., Munday and Washington 2017), 2) the interannual variability (e.g., Dieppois et al. 2015), and/or 3 ) trends over time in the variable of interest (e.g., Williams et al. 2012). Given the scale of differences in model rainfall climatologies in this region, this study will focus on the mean state, as the processes linked to the higher-order statistical moments of variability and trend would likely be implausible if superimposed on a questionable mean state.

Process-based model evaluation may be of particular use in Africa, which has traditionally not been a focus for model development and where processes may be poorly represented by models (James et al. 2018). Processbased assessments have proven fruitful in southern Africa (e.g., Dieppois et al. 2015; Lazenby et al. 2016; Munday and Washington 2017), East Africa (e.g., Tierney et al. 2015; Yang et al. 2015; Hirons and Turner 2018), and the Sahel (e.g., Cook and Vizy 2006; Biasutti et al. 2009; James et al. 2015). James et al. (2015), for example, used a process-based assessment to identify the mechanisms by which models produced drying in historically dry years. These mechanisms were found not to be the same as those producing drying in reanalysis data. They argued that future drying in the region may not be credible, as the process by which drying occurs is the same spurious process as that found in historical model years. In essence, the models were using the same fictitious overturning circulation to create both historical drought and future drying trends. In the case of the Sahel, the circulation is sufficiently well understood for reanalysis data to be a sensible test of the models. Munday and Washington (2017) used a process-based approach to assess a suite of model simulations of southern African rainfall. They found that differences among model rainfall estimates are related to their simulation of the strength of the Angola low-pressure system in austral summer. The approach with respect to the Angola low differs from the Sahel example of James et al. (2015), as the dynamics of the Angola low are poorly understood. If similar approaches can be established for particular seasons or regions in the Congo basin, then we can begin the process of determining which models are producing plausible rainfall climatologies there, too.

\section{b. The SON wet season}

The Congo basin experiences two rainy seasons; one in March-May (MAM) and one between September and November (SON). The timing of the rainy seasons is associated with the meridional movement of tropical convection through the annual cycle. Mean daily rainfall in these seasons is roughly double that experienced in the dry seasons, June-August (JJA) and DJF, in both model and satellite/gauge datasets (Creese and 
Washington 2016). Observational data indicate SON is wetter than MAM over the majority of the Congo basin, contrasting with East Africa, where MAM constitutes the "long" and more intense rains (Dezfuli 2017). Creese and Washington (2016) found that SON was the wettest season in over $80 \%$ of the CMIP5 coupled models in their sample.

The limited research that has been conducted in the Congo basin on reanalysis and observations has revealed several processes that are important to SON rainfall. A common theme among studies is the role of moisture transport from the Atlantic Ocean in particular affecting the west of the Congo basin. Pokam et al. (2012) identified a maximum in low-level moisture convergence at around $850 \mathrm{hPa}$ in $\mathrm{SON}$, associated with low-level moisture advected from the Atlantic that Sorí et al. (2017), based on a Lagrangian transport model driven by ERA-Interim (ERA-I) reanalysis data, ranks as the most important oceanic source for the Congo basin in this season. The strength of these low-level westerlies (LLWs) is related to rainfall variability in western equatorial Africa where wet years exhibit a distinct westerly jet during both wet seasons (Dezfuli and Nicholson 2013; Nicholson and Dezfuli 2013). Pokam et al. (2014) found that the land-ocean heat contrast in this region plays a crucial role in driving LLW variability in this season. The LLWs form the lower branch of a zonal overturning circulation between June and October, with a subsiding branch over the Gulf of Guinea (Pokam et al. 2014; Cook and Vizy 2016). The variability of this overturning circulation is linked to sea surface temperature (SST) anomalies in the Atlantic, which have been found to have both direct and indirect effects on Congo rainfall variability (Balas et al. 2007).

The Indian Ocean and associated moisture fluxes are also likely to be a considerable influence on the region (Black et al. 2003; Ummenhofer et al. 2009; Dyer et al. 2017), particularly in the east of the region where interactions with topography also contribute to convection and MCS activity (Van Der Ent et al. 2010; Jackson et al. 2009). A recent study using water tagging in the CESM model identified the Indian Ocean as a dominant ocean source of moisture into the Congo basin, with the southwest Indian Ocean contribution roughly $21 \%$ of available moisture in both rainy seasons (Dyer et al. 2017). Studies of East African rainfall have also highlighted the role of the equatorial Indian Ocean zonal overturning cell in determining rainfall variability (Hastenrath 2000), and the Indian Ocean dipole (IOD) has long been understood to influence East African rainfall, with positive IOD phases linked to increased wetting via enhanced low-level moisture convergence and ascent over East Africa (Nicholson 2017; Ummenhofer et al. 2009). Relatedly, it has also been suggested the pressure contrast between the Indian and Atlantic basins could account for zonal differences in rainfall across the Congo basin (Dezfuli 2017). Although later in the annual cycle of rainfall than the SON rains, Dezfuli et al. (2015) identify a zonal asymmetric pattern (ZAP) in the southern half of central Africa during December to March, where opposite signs in rainfall occur in the western $\left(10^{\circ}-30^{\circ} \mathrm{E}\right)$ and eastern $\left(30^{\circ}-40^{\circ} \mathrm{E}\right)$ subdomains. Wet periods in eastern central Africa are characterized by enhanced westerlies into the basin, caused by the contrast between low pressure in the southwest Indian Ocean and high pressure over the equatorial Atlantic. These westerlies converge at the East African topography, initiating convection as part of a zonal overturning cell, and intensifying wetting in the east.

Both the northerly components of the midlevel African easterly jet (AEJ-N) and southerly components of the midlevel African easterly jet (AEJ-S) are important circulation features in SON. While the AEJ-N is present throughout the year, the AEJ-S is most clearly defined as a midlevel jet between August and November (Nicholson and Grist 2003). Both jets are a result of strong meridional surface temperature gradients between the equator and subtropics. Previous research has found that interannual rainfall variability in the West African Sahel appears to be linked to the strength and location of the AEJ-N; wet years tend to feature a weaker and more poleward jet, whereas dry years feature a stronger and more equatorward jet (Newell and Kidson 1984; Fontaine et al. 1995; Kanamitsu and Krishnamurti 1978; Grist and Nicholson 2001). Links between rainfall variability and zonal wind have also been identified in western equatorial Africa; Dezfuli and Nicholson (2013) found that in both the east and western subdomains, wet years feature weaker midlevel easterlies across the basin than in dry years.

Nicholson and Grist (2003) found that the tropical rainband is most intense when both components of the jet are well developed, that is, between August and November. The presence of the AEJ-S during SON has been linked to strong MCS activity during SON. Jackson et al. (2009) identified a maximum in MCS activity in a region of strong convergence found to the right of the entrance region of the AEJ-S, as would be expected from the "jet streak" model (Uccellini and Johnson 1979). This maximum in midlevel convergence is suggested to enhance upward motion from the surface and contribute to higher MCS activity. As the AEJ-S is only present during SON, they hypothesized that this may be why this season appears to have more intense rainfall than during MAM.

Previous research has begun to assess the relative role that processes such as water vapor flux play in producing 
rainfall in different coupled models, as SON rainfall can vary by as much as a factor of 3 among CMIP5 models. Following from Pokam et al.'s (2012) work on moisture convergence, Creese and Washington (2016) found that rainfall across CMIP5 models in SON is positively correlated with low-level moisture flux from the western boundary of the Congo basin (the Atlantic coast); that is, wetter models have greater moisture influx from the Atlantic. In contrast, MAM and DJF experience much stronger positive correlations with moisture inflow at the northern and eastern boundaries of the basin, indicating that fluxes from the northeast and across the Indian Ocean are most important for discriminating between coupled model rainfall in those seasons. These results indicate that the tendency for models to be wet or dry in SON is potentially related to their simulation of the climatology of the Atlantic sector. Given the clear tendency for SON to be wetter than MAM in most models, and the distinct east and west rainfall patterns that models produce, this indicates that the rainfall-producing processes across models in this season are worthy of investigation.

\section{c. Aims}

This paper aims to answer the following questions:

1) What are the preferred locations of model rainfall in the Congo basin in SON, and do these differ across coupled models in CMIP5?

2) Are model differences in rainfall linked to Atlantic or Indian Ocean SST biases?

3) How do these biases relate to the regional circulation, and what other elements of the regional circulation, for example the African easterly jets, help to explain model differences in rainfall?

The paper is structured as follows: Section 2 describes the data and methods used in this study. Section 3 addresses the characterization of model rainfall climatology in SON in CMIP5 models, section 4 explores whether model rainfall is related to known SST biases, and we use composite analysis in section 5 to determine possible rainfall-producing mechanisms in wet and dry models. We discuss the results and conclude in sections 6 and 7 , respectively.

\section{Data and methods}

The Congo basin domain used in this study is $8^{\circ}-35^{\circ} \mathrm{E}$, $10^{\circ} \mathrm{S}-10^{\circ} \mathrm{N}$ (red box, Fig. 1). The western (eastern) subdomain comprises grid boxes between $8^{\circ}$ and $21^{\circ} \mathrm{E}$ $\left(21^{\circ}-35^{\circ} \mathrm{E}\right)$ and $10^{\circ} \mathrm{S}$ to $10^{\circ} \mathrm{N}$. The coupled model data in this study are output from CMIP5 (Taylor et al. 2012). A spectrum of 17 models ranging from wet to dry over the Congo basin with the required variables (rainfall, SST, specific humidity, $u$ and $v$ winds, omega, evaporation, and mean sea level pressure) were selected (Table 1). Data are used from both the historical (coupled) experiments and the AMIP experiments, which use an atmosphereonly model forced with observed SSTs. Monthly and seasonal means for the September-November season were calculated over the period 1979-2005, which is the available period for the AMIP experiments. All CMIP5 data have been interpolated to a common grid of $1^{\circ} \times 1^{\circ}$ to allow for easy comparison across models; a step to which the results are insensitive.

ERA-I and NCEP-NCAR (NCEP) reanalysis and observational rainfall datasets (Table 2) are used as initial points of comparison with coupled models. ERA-I (Dee et al. 2011) is later used as a comparison for processes found in composite analyses. Observed SST data are taken from the HadISST2 dataset (Titchner and Rayner 2014).

Composite analysis is used throughout this study to compare the climatological mean state of models that tend to be wet or dry. Each composite includes the four wettest or driest models defined as the upper and lower quartiles of the samples in each of the western and eastern subdomains (Table 3). A metric of difference between the composites is modified from Creese and Washington (2016) and is represented by stippling. Stipples occur under the following conditions: 1 ) where all wet model values are larger or smaller than all dry model values (large dots); 2) where all wet model values are greater or smaller than the dry mean, depending on the direction of difference (squares); 3) where all dry models are greater or smaller than the wet mean, depending on the direction of difference (crosses); and 4) where both 2 and 3 are true (small dots).

\section{Characterizing model rainfall}

There are distinct zonal differences in the location of SON rainfall across the studied samples of CMIP5 models (Fig. 1). Many models show distinct western (e.g., CMCC-CM, GISS-E2-R, MPI-ESM-LR) or eastern (e.g., NorESM1-M, ACCESS1.3, CCSM4, CSIRO Mk3.6.0) rainfall maxima, including some models that show two distinct rainfall maxima (e.g., MRI-CGCM3, HadGEM2-ES). The ensemble mean model (fourth row, center) smooths much of the spatial variability between individual models and is not similar to any individual model. This implies that the use of ensemble mean model is misleading, as found in Creese and Washington (2016). Consistent with Washington et al. (2013) we find substantial variations between satellite, gauge, and reanalysis products.

The presence of distinct east and west rainfall maxima raise the possibility that the processes influencing 
TABLE 1. CMIP5 models used in this study.

\begin{tabular}{|c|c|c|}
\hline Model & Institute & Reference \\
\hline ACCESS1.3 & $\begin{array}{l}\text { Commonwealth Scientific and Industrial Research } \\
\text { Organisation and Bureau of Meteorology Australia (CSIRO-BoM) }\end{array}$ & Collier and Uhe (2012) \\
\hline BCC_CSM1.1 & Beijing Climate Center (BCC) & Wu et al. (2013) \\
\hline CCSM4 & National Center for Atmospheric Research (NCAR) & Gent et al. (2011) \\
\hline CESM1-CAM5 & National Center for Atmospheric Research (NCAR) & Neale et al. (2012) \\
\hline CMCC-CM & Centro Euro-Mediterraneo per I Cambiamenti Climatici (CMCC) & Scoccimarro et al. (2011) \\
\hline CNRM-CM5 & $\begin{array}{l}\text { Centre National de Recherches Météorologiques/Centre Européen de } \\
\text { Recherche et de Formation Avancée en Calcul Scientifique } \\
\text { (CNRM-CERFACS) }\end{array}$ & Voldoire et al. (2013) \\
\hline CSIRO Mk3.6.0 & $\begin{array}{l}\text { Commonwealth Scientific and Industrial Research Organisation in } \\
\text { collaboration with Queensland Climate Change Centre of } \\
\text { Excellence (CSIRO-QCCCE) }\end{array}$ & Jeffrey et al. (2013) \\
\hline EC-EARTH & $\begin{array}{l}\text { EC-Earth Consortium: European Centre for Medium-Range } \\
\text { Weather Forecasts (ECMWF) and other European institutes }\end{array}$ & Hazeleger et al. (2010) \\
\hline FGOALS-g2 & $\begin{array}{l}\text { State Key Laboratory of Numerical Modeling for Atmospheric } \\
\text { Sciences and Geophysical Fluid Dynamics (LASG) and Institute of } \\
\text { Atmospheric Physics (IAP) }\end{array}$ & Li et al. (2013) \\
\hline GFDL CM3 & NOAA Geophysical Fluid Dynamics Laboratory (NOAA GFDL) & Donner et al. (2011) \\
\hline GISS-E2-R & NASA Goddard Institute for Space Studies (GISS) & Schmidt et al. (2014) \\
\hline HadGEM2-ES & Met Office Hadley Centre (MOHC) & Jones et al. (2011) \\
\hline IPSL-CM5A-MR & L'Institut Pierre-Simon Laplace (IPSL) & Dufresne et al. (2013) \\
\hline MIROC5 & $\begin{array}{l}\text { Atmosphere and Ocean Research Institute (The University of Tokyo), } \\
\text { National Institute for Environmental Studies, and Japan Agency } \\
\text { for Marine-Earth Science and } \\
\text { Technology (MIROC) }\end{array}$ & Watanabe et al. (2010) \\
\hline MPI-ESM-LR & Max Planck Institut für Meteorologie (MPI-M) & Marsland et al. (2003) \\
\hline MRI-CGCM3 & Meteorological Research Institute (MRI) & Yukimoto et al. (2012) \\
\hline NorESM1-M & Norwegian Climate Centre (NCC) & Bentsen et al. (2013) \\
\hline
\end{tabular}

rainfall differ across the basin in coupled models. Figure 2 shows the correlation between rainfall in the west of the basin and in the east of the basin across the suite of models for each of the 12 months. Figure 2 highlights that, in the majority of months, rainfall is strongly correlated between both halves of the basin; that is, models that are wet in the east also tend to be wet in the west. This suggests a common process may be governing model wetness across the basin in these seasons. However, in August-November, rainfall in the east and west are not correlated, suggesting that the processes related to rainfall in each subdomain may be distinct. Studies conducted using reanalysis data on interannual time scales support this hypothesis, as local processes have been identified that may favor rainfall only in the west of the basin, including the zonal overturning circulation with a downward branch over the Gulf of Guinea (Cook and Vizy 2016) and moisture advection via lowlevel westerlies from the Atlantic (Pokam et al. 2014).

To help identify the processes associated with differences in rainfall, composites are created of the four wettest and four driest models in each subdomain (based on SON mean rainfall; Table 3). Figure 3 shows these composites for rainfall. In addition to showing the magnitude of rainfall differences over the subdomains,
Fig. 3 also highlights significant differences in the surrounding region. For example, in both composites, a wet subdomain is associated with a dry equatorial western Indian Ocean. For the eastern composites, wetness is also associated with drying at the Atlantic coast between north Angola and Gabon. These findings indicate that local SSTs may play a role in determining model wetness or dryness in both subdomains.

\section{Influence of tropical Atlantic and Indian Ocean sea surface temperatures}

SST biases are well documented in coupled models and many studies have linked them to biases in the hydrological cycle (Wang et al. 2014; Richter et al. 2016; Prodhomme et al. 2014; Joseph et al. 2012; Bollasina and Ming 2013; Large and Danabasoglu 2006; Eichhorn and Bader 2017). The Congo basin is adjacent to two ocean basins, and previous research has linked moisture advected from the Atlantic and Indian Oceans to rainfall variability (e.g., Pokam et al. 2012; Dyer et al. 2017). Therefore, an evaluation of SST biases in relation to model rainfall biases is a useful first-order assessment.

All CMIP5 models in this study, apart from CSIRO Mk3.6.0, have a well-documented (e.g., Wang et al. 
TABLE 2. Identity and characteristics of reanalysis and satellite/gauge datasets used in this study.

\begin{tabular}{|c|c|c|c|c|}
\hline Dataset & Full name and institute & $\begin{array}{l}\text { Native horizontal } \\
\text { resolution }\end{array}$ & Dates used & Reference \\
\hline ERA-Interim & $\begin{array}{l}\text { European Centre for Medium-Range } \\
\text { Weather Forecasts }\end{array}$ & $0.7^{\circ} \times 0.7^{\circ}$ & 1979-2005 & Dee et al. (2011) \\
\hline NCEP-NCAR & $\begin{array}{l}\text { National Centers for Environmental } \\
\text { Prediction (NCEP) and National Center } \\
\text { for Atmospheric Research (NCAR) }\end{array}$ & $2.5^{\circ} \times 2.5^{\circ}$ & $1971-2000$ & Kalnay et al. (1996) \\
\hline CRU & $\begin{array}{l}\text { Climate Research Unit, University of East } \\
\text { Anglia (v3.10) }\end{array}$ & $0.5^{\circ} \times 0.5^{\circ}$ & 1979-2005 & Harris et al. (2014) \\
\hline GPCC & $\begin{array}{l}\text { Global Precipitation Climatology Centre, } \\
\text { Deutscher Wetterdienst, World } \\
\text { Meteorological Organization }\end{array}$ & $0.5^{\circ} \times 0.5^{\circ}$ & 1979-2005 & Schneider et al. (2015) \\
\hline CMAP & $\begin{array}{l}\text { Climate Prediction Centre Merged Analysis } \\
\text { of Precipitation, NOAA, NCEP }\end{array}$ & $2.5^{\circ} \times 2.5^{\circ}$ & 1979-2005 & Xie and Arkin (1997) \\
\hline TRMM & $\begin{array}{l}\text { Tropical Rainfall Measuring Mission, NASA } \\
\text { Goddard Space Flight Center, Japanese } \\
\text { Aerospace Exploration Agency }\end{array}$ & $0.25^{\circ} \times 0.25^{\circ}$ & 1998-2014 & Huffman et al. (2007) \\
\hline
\end{tabular}

2014) strong warm bias in the tropical eastern Atlantic (Fig. 4). This is a common feature of eastern tropical ocean basins in coupled models (Richter 2015; Zuidema et al. 2016). While the cause of the bias is not fully understood, it likely relates to the location of the AngolaBenguela frontal zone (ABFZ), and the inability of models to produce adequate stratocumulus cloud coverage in the southeast Atlantic (Xu et al. 2014; Richter et al. 2012). The proximity of the bias to the western Congo basin invokes the possibility that it may impact the provision and transport of water vapor in this region. Biases in the Indian Ocean are of much smaller magnitude than in the Atlantic. These are generally less consistent between models, with some showing slight warm biases (e.g., CCSM4, BCC_CSM1.1) and others slight cold biases (e.g., GFDL CM3, MIROC5).

As a first-order assessment of how rainfall may be influenced by SSTs, atmosphere-only (AMIP) versions of the CMIP5 models are assessed. In AMIP experiments, the atmosphere model is forced with observed SSTs, and so comparisons between CMIP and AMIP runs are a useful indicator of model biases that may be produced by ocean-atmosphere coupling in coupled models. Figure 5 shows the difference in long-term mean rainfall between 17 CMIP and AMIP model experiments. It indicates that the largest differences between
CMIP and AMIP tend to be in the western half of the Congo basin and over the Gulf of Guinea ( $\sim 2$ $4 \mathrm{~mm} \mathrm{day}^{-1}$ ). In the east, the difference between CMIP and AMIP is smaller in most models. It is also interesting to note that CSIRO Mk3.6.0, the only model to have a mean cold bias $\left(-1.9^{\circ} \mathrm{C}\right)$ in the tropical Atlantic, is also the only model where AMIP is wetter than CMIP in the west. Despite it clearly having a different coupling error than most models, this indicates that it may respond to SST biases in a similar way, that is, warm (cold) biases are related to more (less) rainfall near the Atlantic coast.

Figure 6 quantifies the differences between CMIP and AMIP in the annual cycle and compares it to the annual cycle of the Atlantic warm bias, the largest and most persistent bias in the region. Boxplots represent the CMIP minus AMIP values in the west (Fig. 6a) and east (Fig. 6b) of the Congo, for all models in each month. Figure 6 highlights that the difference between CMIP and AMIP in the western Congo closely follows the annual cycle of the Atlantic SST bias, particularly in July to October where high median CMIP-AMIP differences $\left(0.99-1.58 \mathrm{~mm} \mathrm{day}^{-1}\right)$ correspond to the largest SST biases $\left(1.90^{\circ}-2.47^{\circ} \mathrm{C}\right)$. Between January and April, small SST biases correspond with much smaller differences between AMIP and CMIP. The boxplot for the

TABLE 3. Models used in wet and dry composites.

\begin{tabular}{|c|c|c|c|c|c|c|c|}
\hline \multicolumn{4}{|c|}{ Models in west composites } & \multicolumn{4}{|c|}{ Models in east composites } \\
\hline Wet & $\mathrm{mm}_{\text {day }}{ }^{-1}$ & Dry & $\mathrm{mm}_{\text {day }}{ }^{-1}$ & Wet & $m m$ day $^{-1}$ & Dry & $m m$ day $^{-1}$ \\
\hline MPI-ESM-LR & 7.22 & MRI-CGCM3 & 4.16 & ACCESS1.3 & 9.0 & GISS-E2-R & 3.47 \\
\hline NorESM1-M & 6.88 & CESM1 (CAM5) & 4.70 & MIROC5 & 7.74 & CNRM-CM5 & 3.69 \\
\hline IPSL-CM5A-MR & 6.73 & HadGEM2-ES & 4.75 & NorESM1-M & 7.51 & CMCC-CM & 3.99 \\
\hline MIROC5 & 6.63 & CMCC-CM & 4.84 & CCSM4 & 7.44 & MRI-CGCM3 & 4.40 \\
\hline
\end{tabular}



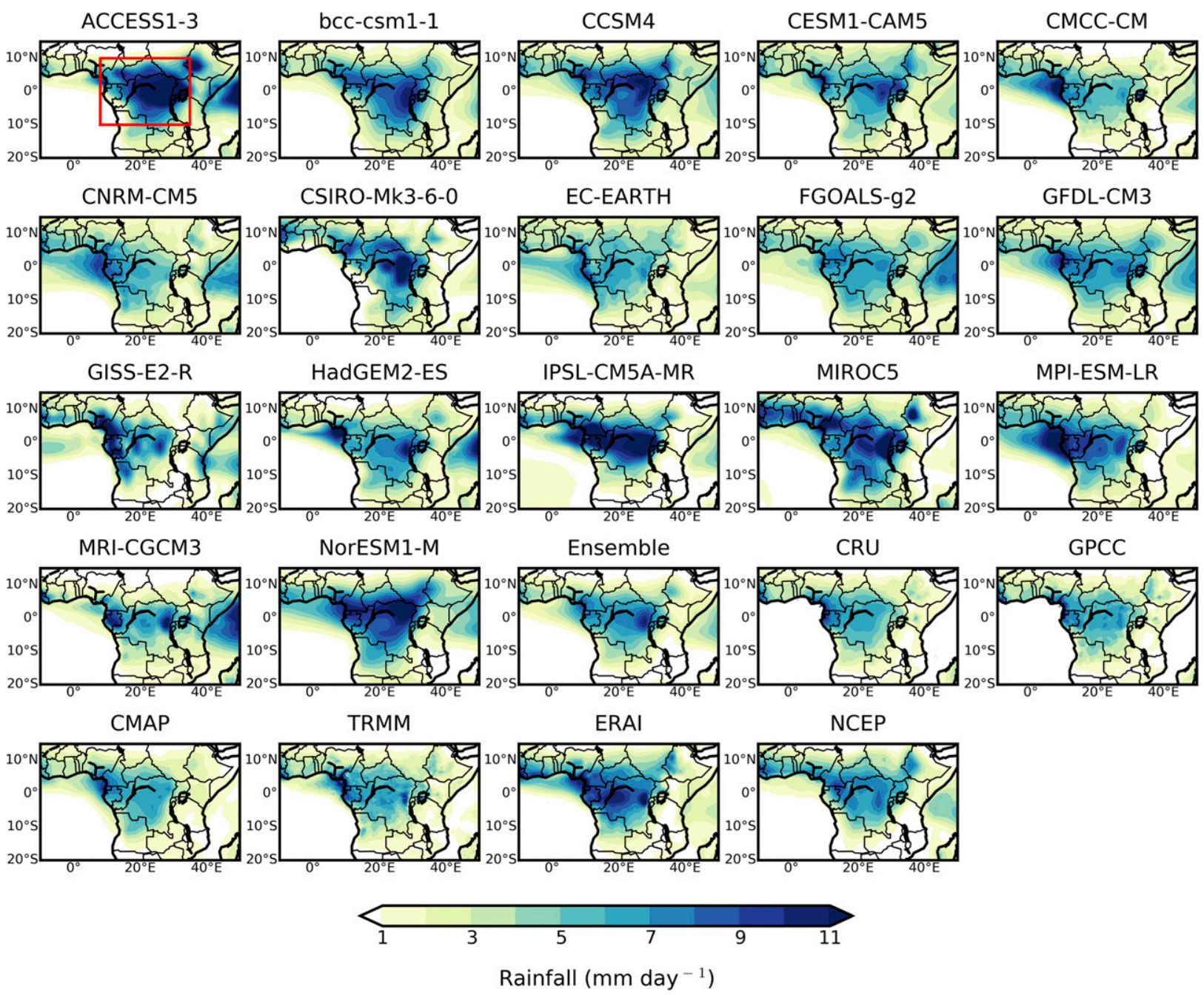

FIG. 1. Long-term mean (1979-2005) SON rainfall $\left(\mathrm{mm} \mathrm{day}^{-1}\right)$ for 17 CMIP5 models, ensemble mean, reanalysis, and satellite/gauge products. The red box indicates the whole Congo basin domain used in this study $\left(8^{\circ}-35^{\circ} \mathrm{E}, 10^{\circ} \mathrm{S}-10^{\circ} \mathrm{N}\right)$.

eastern Congo (Fig. 6b) suggests that SST biases in general are less important for differentiating between wet and dry models in this region, as CMIP and AMIP values are much more similar. In addition, throughout the SON period, CMIP-AMIP differences in the east do not as obviously track the cycle of Atlantic SST biases, suggesting that this particular bias has limited effect on relative model wetness in the eastern Congo.

While AMIP experiments are a useful comparison point, they must be treated with some caution for two reasons. First, they do not allow for interaction between the atmosphere and ocean, so atmospheric processes that would induce a feedback from the ocean in the real world are not represented. Second, they represent a "correction" of SSTs on a global scale, and so AMIP simulations do not to isolate the effects of correcting a specific bias such as the one in the southeast Atlantic.
Nevertheless, CMIP-AMIP comparisons give a good first indication of the impact of SST biases.

\section{Identifying processes related to rainfall differences}

The results so far highlight that

1) Rainfall in the west is not correlated with rainfall in the east across CMIP5 models, so different processes may be dominant in maintaining rainfall in the east and the west subdomains.

2) CMIP-AMIP differences are larger in the western Congo than in the east, suggesting a larger influence of SSTs in this subdomain.

The following section attempts to identify a chain of processes that explain rainfall differences in each 


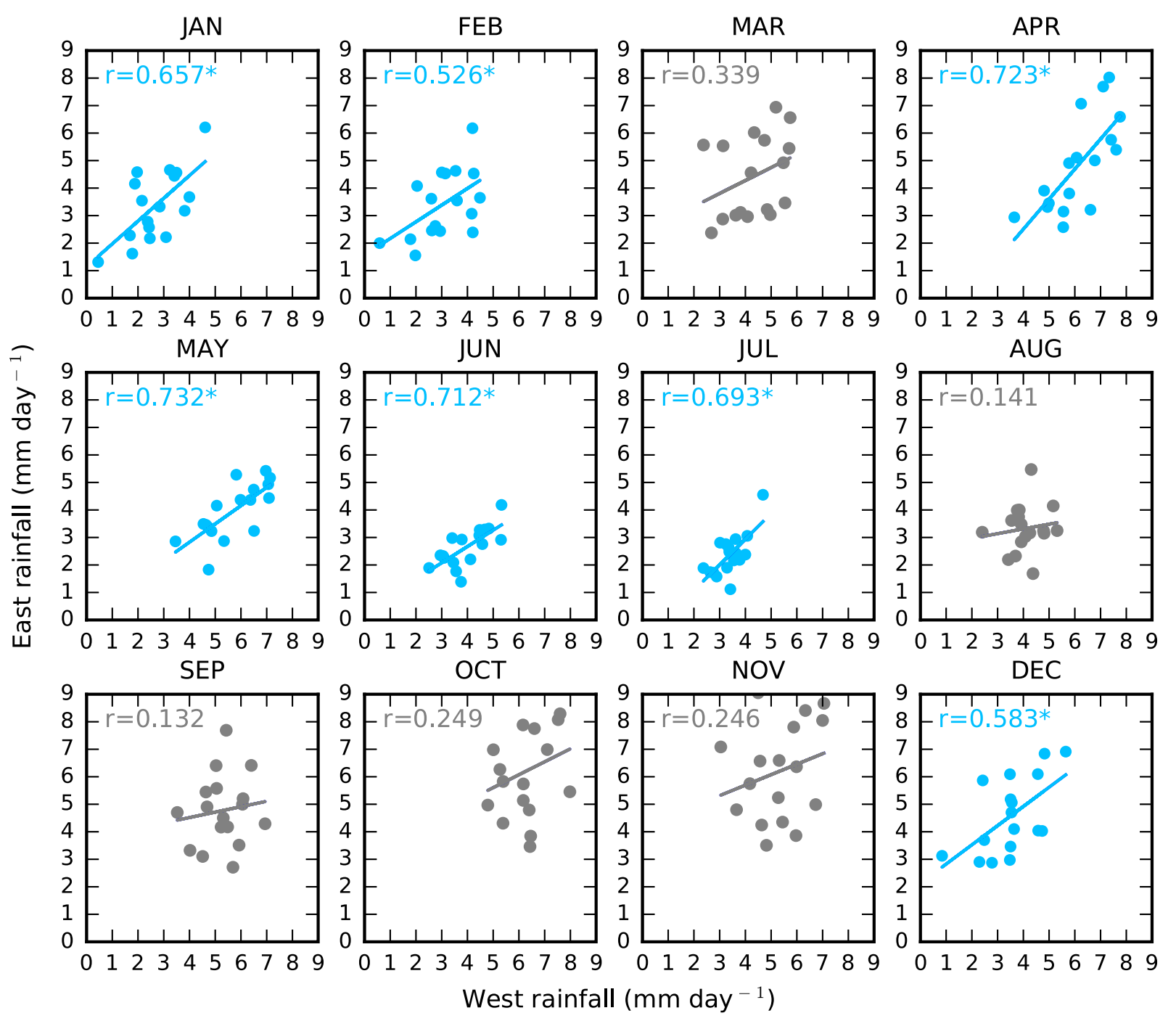

FIG. 2. Scatterplots showing relationship between long-term mean $(1979-2005)$ rainfall $\left(\mathrm{mm} \mathrm{day}^{-1}\right)$ in the west $\left(8^{\circ}-21^{\circ} \mathrm{E}, 10^{\circ} \mathrm{S}-10^{\circ} \mathrm{N}\right)$ and in the eastern $\left(21^{\circ}-35^{\circ} \mathrm{E}, 10^{\circ} \mathrm{S}-10^{\circ} \mathrm{N}\right)$ Congo basin. Blue plots and $r$ values with asterisks show relationships that are significant at the $95 \%$ level; gray plots and $r$ values show relationships that are not significant at the $95 \%$ level.

subdomain in turn. ERA-I is included in the following plots to give a sense of whether wet or dry composites are closest to an observational "best guess"; however, comparison with reanalysis is not the dominant method for assessing model credibility.

\section{a. Processes in the west}

To help identify how model rainfall may be related to the Atlantic SST bias, wet and dry western Congo composites are shown in Fig. 7. The largest bias in both wet and dry models is in the tropical eastern Atlantic, where models feature large $\left(>2^{\circ} \mathrm{C}\right)$ warm biases. The bias is consistently warmer (approximately $1^{\circ}-2^{\circ} \mathrm{C}$ ) and more equatorward in the wet composite. In addition, wet models also feature a cold anomaly, relative to dry models, in the western Atlantic, near the South American coast. A similar warm-cold pattern is evident in the Indian Ocean, though the magnitudes of both the bias and difference between wet and dry models are much weaker.

Given its proximity to the western Congo, it is hypothesized that the warm Atlantic SST bias is one of the dominant influences on model wetness. To further understand the Atlantic warm bias in this season in particular, Fig. 8 shows the annual cycle of the Atlantic coast SST bias $\left(5^{\circ}-8^{\circ} \mathrm{E}, 25^{\circ} \mathrm{S}-2^{\circ} \mathrm{N}\right.$; see ensemble plot of Fig. 4) in the west composites. For wet models in the west of the basin (Fig. 4a), the Atlantic SST warm bias is present in all months between $0^{\circ}$ and $15^{\circ} \mathrm{S}$, but is strongest from June to October between $0^{\circ}$ and $5^{\circ} \mathrm{S}$. In the dry 
a) Wet, west

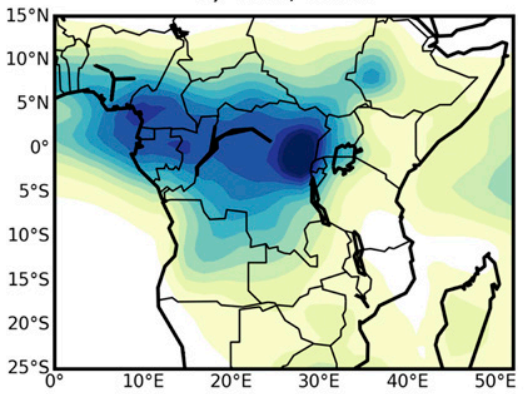

d) Wet, east

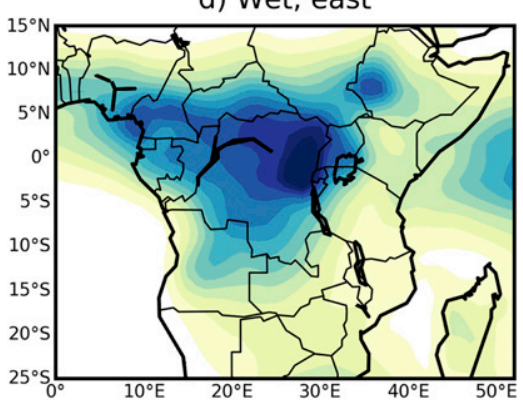

b) Dry, west

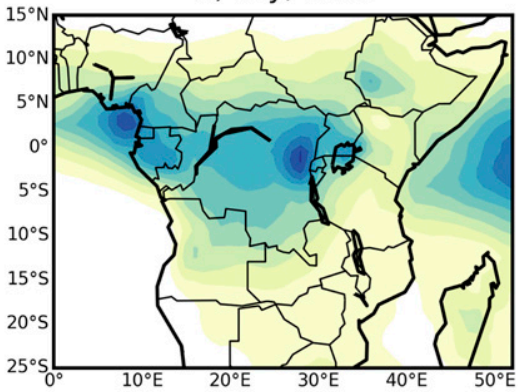

e) Dry, east

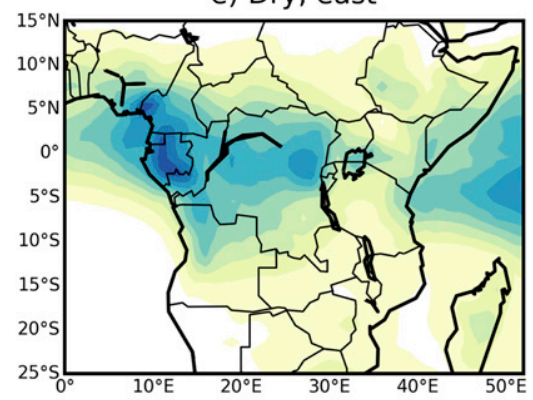

c) Difference, west

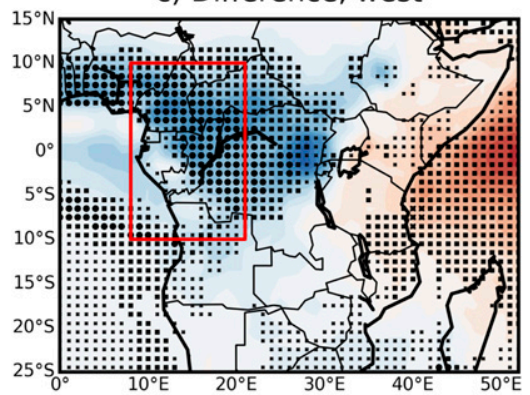

f) Difference, east

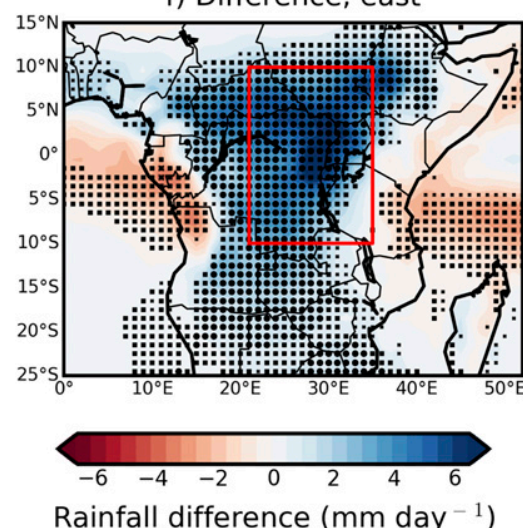

Rainfall ( $\mathrm{mm}$ day ${ }^{-1}$ )

FIG. 3. Long-term mean (1979-2005) rainfall (mm day ${ }^{-1}$ ) composites of (a),(d) four wettest models, (b),(e) four driest models, and (c),(f) the wet minus dry difference in the west and east of the basin, respectively. The red box shows the location of the subdomain. Stipples occur under the following conditions: 1) where all wet model values are larger or smaller than all dry model values (large dots); 2) where all wet model values are greater or smaller than the dry mean, depending on the direction of difference (squares); 3 ) where all dry models are greater or smaller than the wet mean, depending on the direction of difference (crosses); and 4) where both 2 and 3 are true (small dots).

models, the northerly bias is much weaker, and the strongest bias is farther south, centered on $15^{\circ} \mathrm{S}$. The wet minus dry difference shows that the largest amplitude and most consistent difference is centered over August and the SON rainy season; stipples indicate that all wet models have a bias larger than the dry model mean. Correlation analysis across all models between mean rainfall in the western Congo basin and mean-SST bias in the studied box along the tropical Atlantic coast shows that this relationship holds across the suite of models $(r=0.67, p<0.007)$.

One way in which a warm SST bias could affect Congo rainfall is by enhancing available moisture via increased evaporation. Composites of evaporation in the Gulf of Guinea in wet and dry models are shown in Fig. 9. For most of the Gulf of Guinea region and the central African coast, evaporation is significantly higher in wet models across most of the central east Atlantic. A comparison with ERA-I shows that the dry models are closer to the reanalysis estimate than wet models, further suggesting that the stronger SST bias in wet models may be causing enhanced evaporation.
Higher evaporation rates in wet models is hypothesized to be related to enhanced moisture advection through the western boundary of the Congo. This is based on both observational studies (Pokam et al. 2012, 2014; Cook and Vizy 2016) and model analysis (Creese and Washington 2016). The long-term mean $925-\mathrm{hPa}$ moisture flux ( $q$ flux) and $q$-flux convergence for the composites and ERA-I is shown in Fig. 10. ERA-I is a useful comparison point for wind-related processes, as dynamical components such as wind are much better constrained than heavily parameterized processes such as rainfall. Both wet and dry models show some similarity to ERA-I; northeasterly flow over the southeast Atlantic, which recurves into northwesterly flow at the equator. This is promising as it suggests that models are producing credible circulation features; it also indicates that wet/dry differences in the west are the result of differences in the amplitude of the same mechanism rather than distinct mechanisms. The wet minus dry difference plot shows that wet models have enhanced wind convergence over the western subdomain and stronger westerlies in the central tropical Atlantic and at 

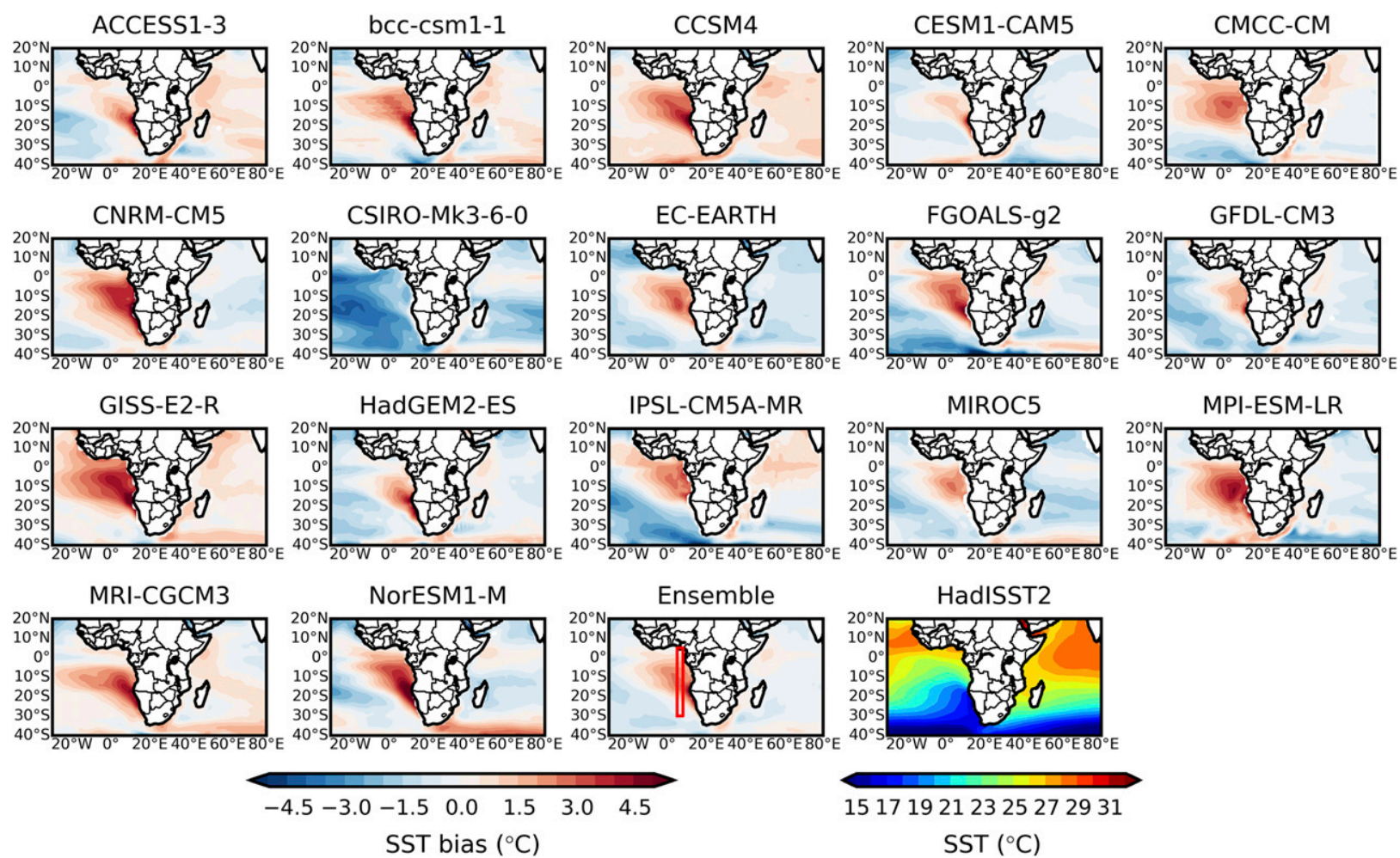

151719212325272931

SST $\left({ }^{\circ} \mathrm{C}\right)$

FIG. 4. Long-term mean (1979-2005) SST bias $\left({ }^{\circ} \mathrm{C}\right.$; model minus HadISST2) in SON for all CMIP models and ensemble mean and the HadISST2 observed SST $\left({ }^{\circ} \mathrm{C}\right)$. The red box shows the location of Atlantic SST mean bias in Fig. 8.

the central African coast. In conjunction with Figs. 8 and 9, this suggests that a combination of local convective and circulatory processes is a key driver of rainfall differences in the western Congo.

Studies of interannual variability in reanalysis data find that low-level westerly flow into the Congo basin in SON forms the lower branch of an Atlantic-Congo zonal overturning circulation with uplift over the continent (Pokam et al. 2014; Cook and Vizy 2016). Figure 11 shows the vertical profile of omega, averaged between $3^{\circ} \mathrm{S}$ and $3^{\circ} \mathrm{N}$, as a cross section by longitude, for the composites and ERA-I (the purple line shows the longitudinal extent of the western subdomain). Overlain are streamlines of the divergent component of zonal wind and omega. The divergent component of zonal wind has been used as it is the component that is coupled with omega (Cook and Vizy 2016). Over the Atlantic and the western Congo the circulation in both wet and dry models takes the same general form as in ERA-I; a large region of convection over land and subsidence over the ocean; the streamlines show that this is a connected zonally overturning circulation. Previous studies have identified the zonal overturning circulation as a mechanism for advecting moisture into the basin, and Cook and Vizy's (2016) study suggests that in years with above-average SSTs, the zonal overturning circulation is strengthened because of enhanced evaporation and increased westerly moisture flux. However, Fig. 11d shows that while wet models do have enhanced upward motion over the Congo, they do not have correspondingly stronger subsidence over the Atlantic Ocean. Therefore, wet models cannot be said to have a stronger AtlanticCongo overturning circulation. Instead, it appears that warmer SSTs and the associated increase in evaporation drive a local enhancement of convection, leading to greater rainfall over the coastal region.

The Atlantic-Congo cell is one aspect of the equatorial zonal cell; Fig. 11 shows that there are also differences between wet and dry models in the Indian Ocean cell(s). The wet composite features enhanced convection in the eastern Indian Ocean $\left(90^{\circ}-120^{\circ} \mathrm{E}\right)$, coincident with the warm anomaly compared to the dry composite (Fig. 7d). This is connected via an overturning cell to enhanced subsidence over the eastern Indian Ocean and the East African coast, which in turn is connected to outflow from the Atlantic-Congo cell. This may explain why the wet composite features anomalous drying at the East African coast (Fig. 3). In contrast, dry models feature significantly weaker convection in the eastern Indian Ocean, and greater convection in the western 

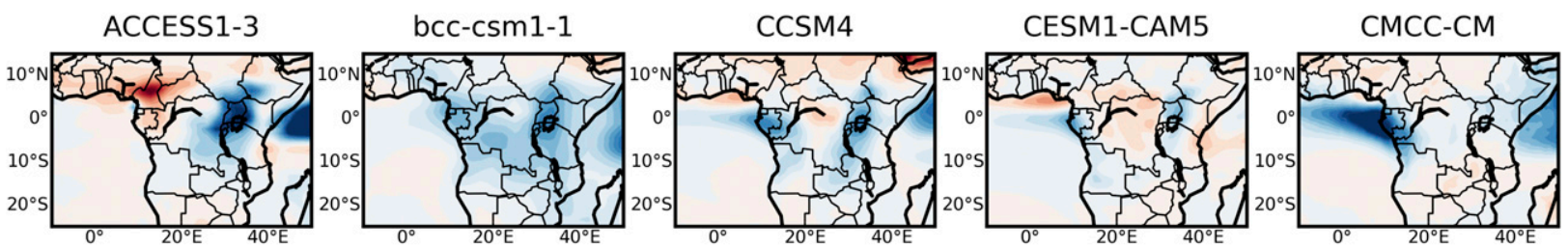

\section{CNRM-CM5}

CSIRO-Mk3-6-0
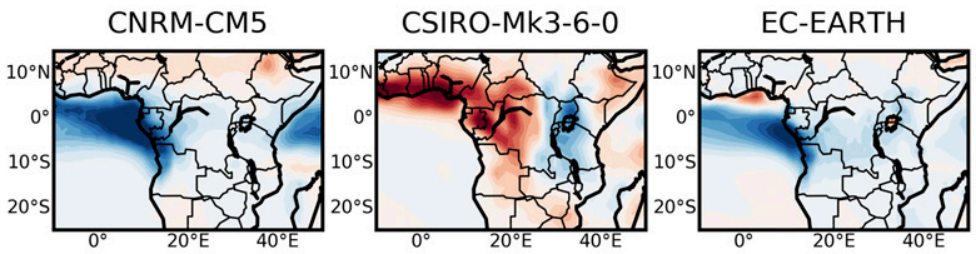

FGOALS-g2

GFDL-CM3
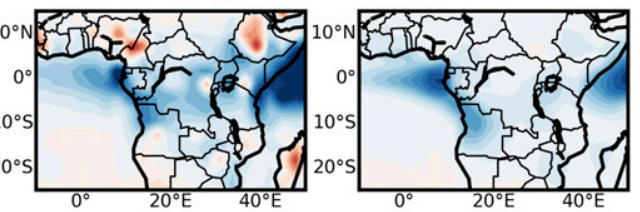

GISS-E2-R

HadGEM2-ES
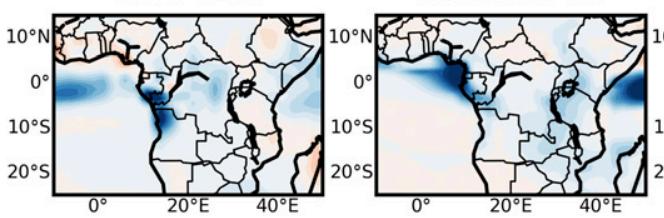

IPSL-CM5A-MR

MIROC5

MPI-ESM-LR
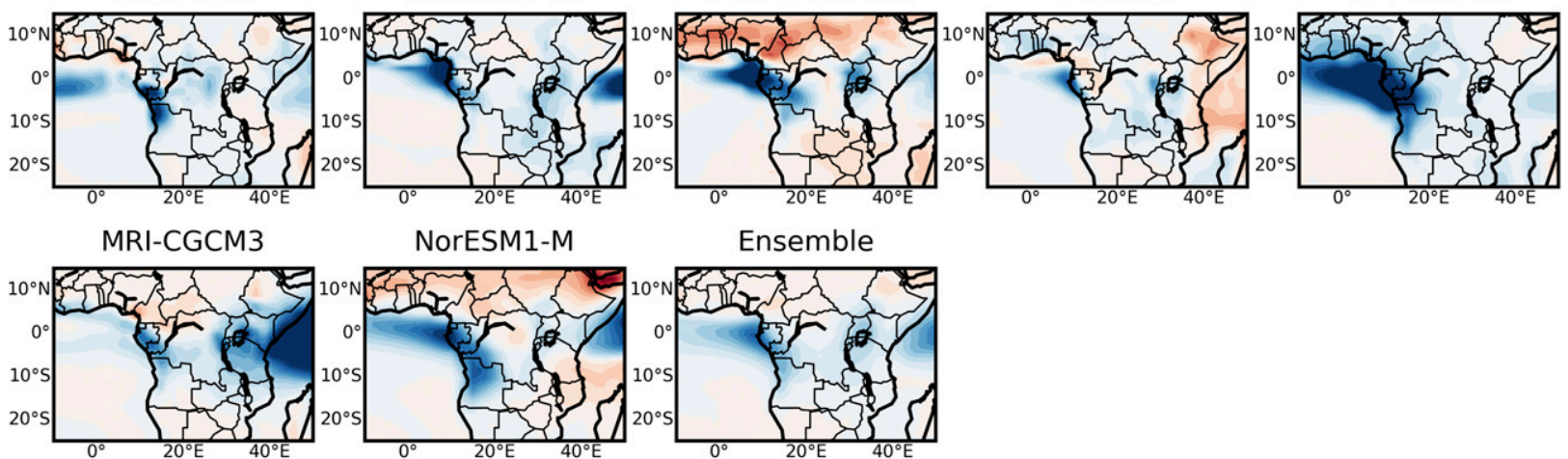

Ensemble
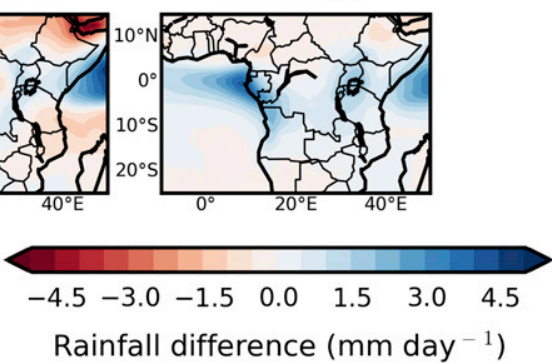

FIG. 5. Long-term mean (1979-2005) CMIP minus AMIP rainfall $\left(\mathrm{mm} \mathrm{day}^{-1}\right)$ in SON for all CMIP5 models and the ensemble mean.

Indian Ocean $\left(50^{\circ}-80^{\circ} \mathrm{E}\right)$. This has two implications. First, as the location of this cell is much farther westward, there is enhanced rainfall in the western Indian Ocean (Fig. 3) compared with wet models. Second, the region of subsidence over the East African coast, present in the wet composite and ERA-I, occupies a much smaller longitudinal region, as the two up-branches are closer together. This may also contribute to dampening a) West

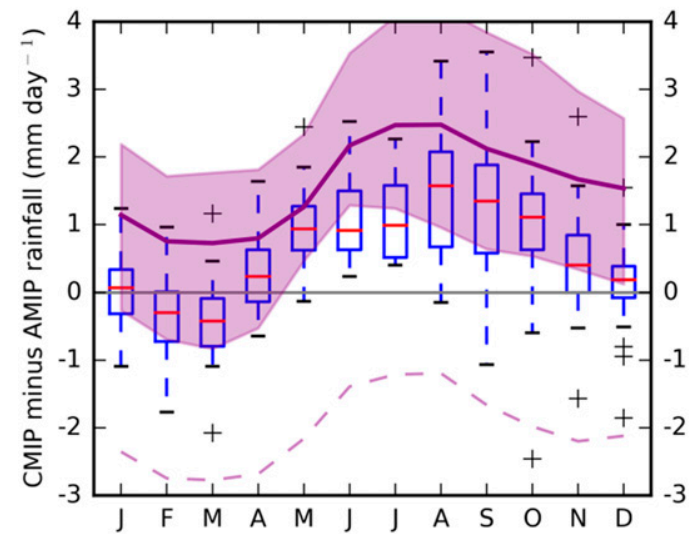

b) East

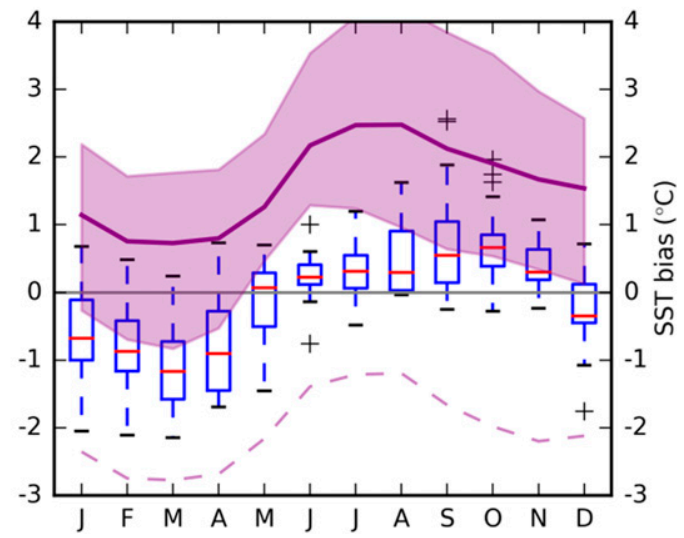

FIG. 6. Annual cycle of long-term mean (1979-2005): CMIP minus AMIP rainfall (mm day ${ }^{-1}$ ) for all models (boxplot); the mean model Atlantic SST bias between $5^{\circ} \mathrm{W}$ and $8^{\circ} \mathrm{E}, 12^{\circ} \mathrm{S}$ and $3^{\circ} \mathrm{N}\left({ }^{\circ} \mathrm{C}\right.$; purple line); and intermodel spread of Atlantic SST biases (purple shaded area; excluding CSIRO Mk3.6.0). The dashed line shows the SST bias in CSIRO Mk3.6.0, the only model to have a consistent cold bias. 
a) HadISST2

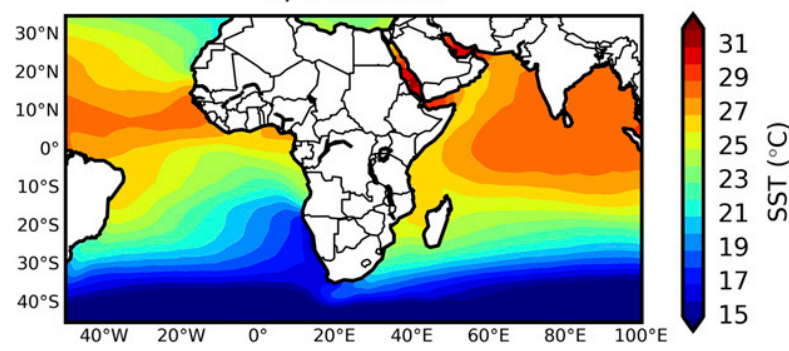

b) Wet models, west

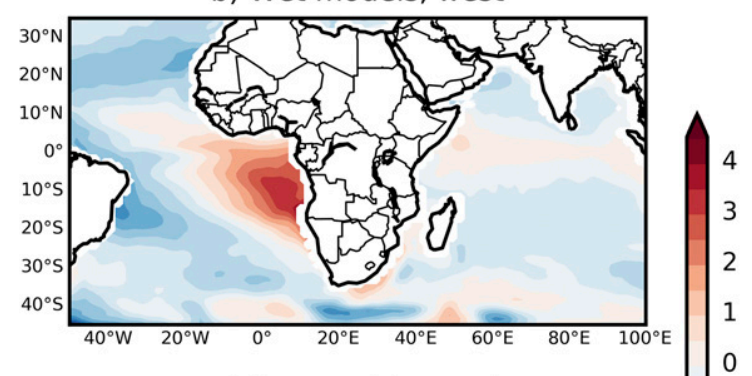

c) Dry models, west

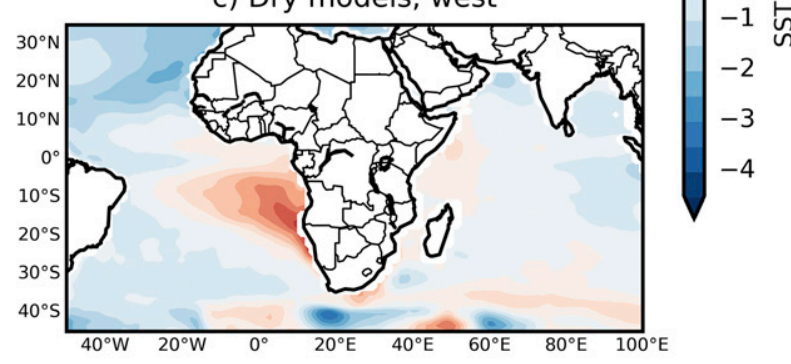

d) Difference, west

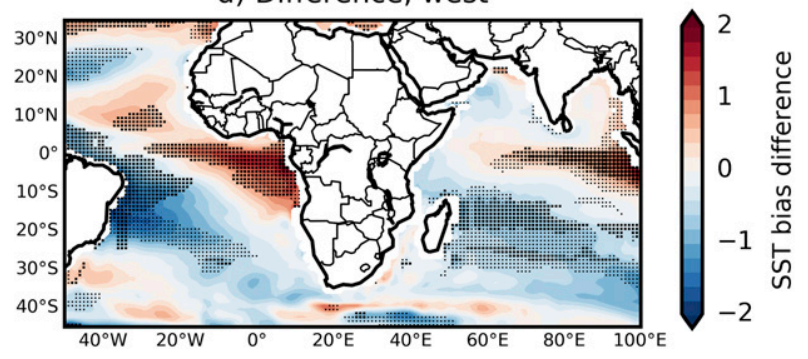

FIG. 7. Long-term mean (1979-2005) SST $\left({ }^{\circ} \mathrm{C}\right)$ in SON in (a) HadISST2 (observed) and SST bias $\left({ }^{\circ} \mathrm{C}\right)$ in (b) western Congo wet composite, (c) western Congo dry composite, and (d) wet minus dry difference between wet and dry composite.

of convection over the Congo, and subsidence from the Indian cell interacts with convection from the Atlantic cell.

\section{b. Processes in the east}

Figures 5 and 6 indicate that differences in model rainfall in the eastern Congo basin are less sensitive to SST biases as in the west. Nevertheless, given the scale of SST biases in coupled models, there could still be SST influences of opposite signs that work to partially cancel each other out and that still represent implausible processes in the models. Figure 12 shows SST differences between the wet and dry composites. There is no significant difference in the warm bias in the tropical Atlantic coastal region between wet and dry models in the east, and additionally no significant difference in evaporation in this region (not shown), again suggesting that the influence of the tropical Atlantic SST bias in enhancing evaporation only manifests locally, and does not extend farther eastward into the basin. Instead, Fig. 12 suggests that eastern Congo model rainfall is connected to more remote SST biases in models. Wet models feature colder central and western Atlantic SSTs, and a small area of consistently warmer SSTs in the tropical eastern Indian Ocean. The western Indian Ocean does not appear to be a significant factor in differentiating between wet and dry models in the eastern Congo basin. In this section, we attempt to identify processes that may be driving the differences between models in the east.

As well as influencing rainfall via enhanced moisture availability, as appears to be the dominant affect in the western Congo, SSTs can also influence the dynamical circulation, including wind direction and intensity, particularly at low levels. Figure 13 shows the low-level $(925 \mathrm{hPa})$ and midlevel $(700 \mathrm{hPa}) q$ flux and $q$-flux convergence climatologies in the composites and ERA-I. At both levels, the models broadly capture the patterns seen in reanalysis. At $925 \mathrm{hPa}$ (Fig. 13a), the key differences between wet and dry models are an enhanced westerly flow from the Atlantic. The enhanced westerly flow from the Atlantic is due to greater recurvature of the southeasterlies, which are also stronger in the wet composite. This resembles that seen in Fig. 10 for the wet/west models. There are two key differences, however. In wet/west models, the flux was more convergent at the coast, whereas in wet/east models the flow is more divergent. In addition, the westerlies in wet/east models extend much farther into the basin. This suggests that greater acceleration (i.e., divergence) of the westerly flow at the Atlantic coast is allowing moisture to penetrate farther inland to the east of the basin in wet models. Wet models also feature enhanced southeasterly flow in the south Indian Ocean, emulating that in the southeast Atlantic.

At $700 \mathrm{hPa}$ (Fig. 13b), the direction of the zonal flux is reversed; both wet and dry models show mean easterly flow, associated with the African easterly jets. However, the wet minus dry difference shows that wet models have anomalous westerlies at the equator. This suggests that one or both components of the AEJ are weaker in wet models. At upper levels $(200 \mathrm{hPa}$; not shown), wet models feature stronger easterlies, particularly to the 
a) Wet models, west

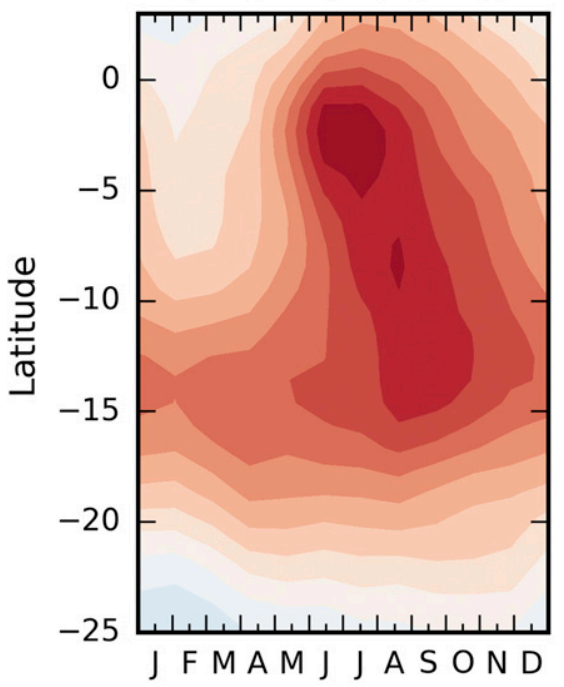

b) Dry models, west

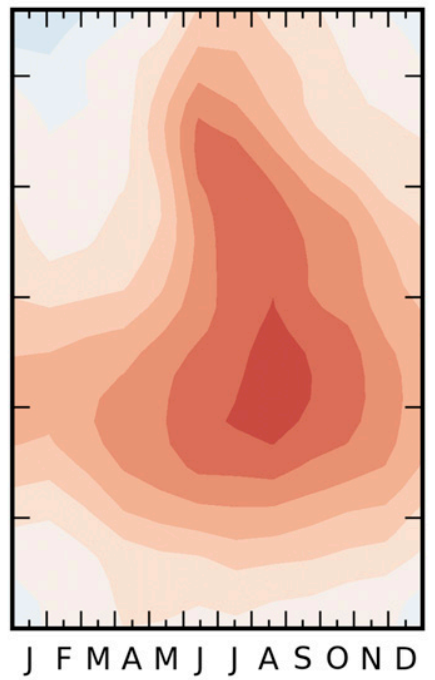

c) Difference, west

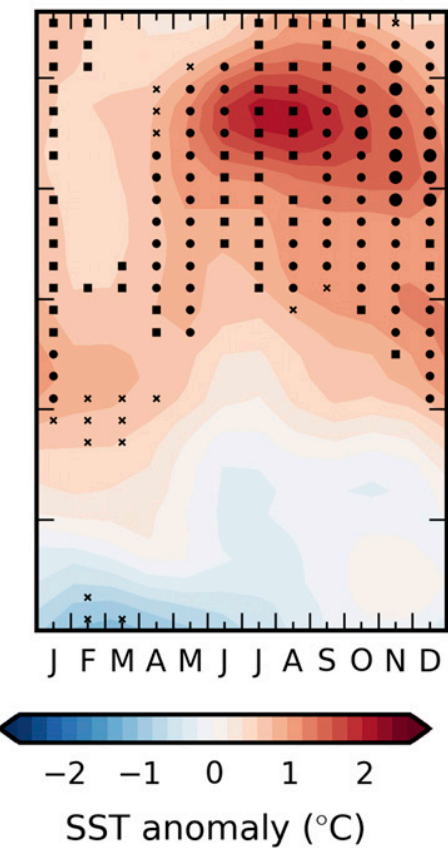

FIG. 8. Annual cycle of long-term mean (1979-2005) SST bias $\left({ }^{\circ} \mathrm{C}\right.$; model minus HadISST2) between $5^{\circ}$ and $8^{\circ} \mathrm{E}$ for the (a) western Congo wet composite, (b) western Congo dry composite, and (c) the wet minus dry difference.

west of $35^{\circ} \mathrm{E}$, which is consistent with a stronger upper branch of the zonal overturning circulation. This finding is also analogous to Dezfuli and Nicholson's (2013) finding that wetter years in observations feature enhanced (reduced) upper-level (midlevel) easterly flow. The role of both low- and midlevel processes, and their connections to the overturning circulation and upperlevel flow, is assessed below.

\section{1) LOW-LEVEL CIRCULATION DIFFERENCES}

Enhanced recurvature of low-level southeasterlies into southwesterlies in the South Atlantic has previously been linked to the South Atlantic high pressure system (SAH) (Nicholson and Grist 2003). The strength of the subtropical highs can also influence (or be influenced by) SSTs, which Fig. 12 highlights are anomalously cold here in wet models. Figure 14 shows the mean sea level pressure (shading) overlain with 925-hPa $q$-flux vectors in the two ocean basins for ERA-I, wet and dry models in the east, and the wet minus dry difference. Wet models have an enhanced and south-shifted SAH compared to dry models; this is significant across the whole suite of models, where correlation between mean sea level pressure in the a) ERAI

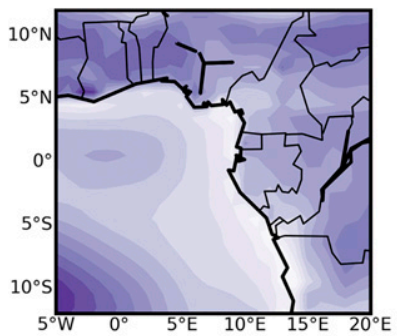

b) Wet, west

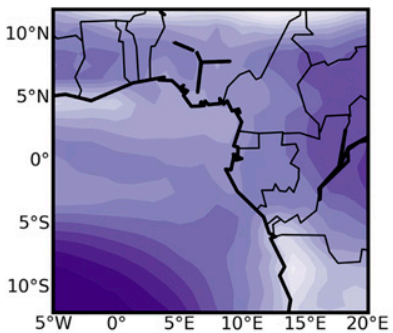

c) Dry, west

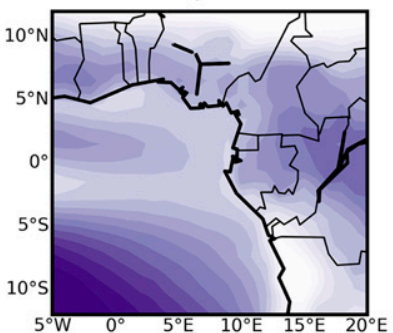

d) Difference, west

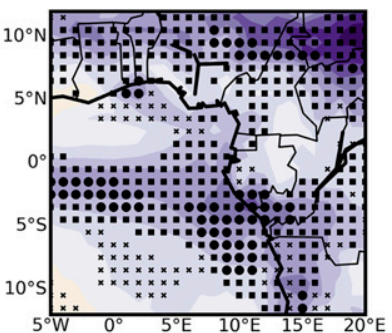

$\begin{array}{lllll}-1.6 & -0.8 & 0.0 & 0.8 & 1.6\end{array}$

Evaporation difference

FIG. 9. Long-term mean (1979-2005) evaporation $\left(\mathrm{mm} \mathrm{day}^{-1}\right.$ ) in SON in (a) ERA-I, (b) western Congo wet composite, (c) western Congo dry composite, and (d) wet minus dry difference. Stipples are as in Fig. 3. 
a) ERAI

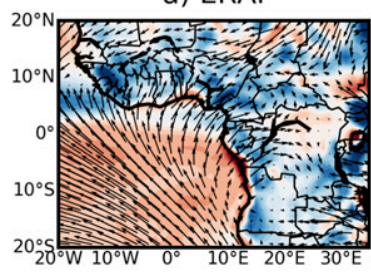

b) Wet, west

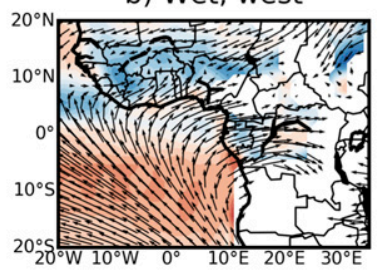

$0.05 \longrightarrow$

$0.05 \rightarrow$

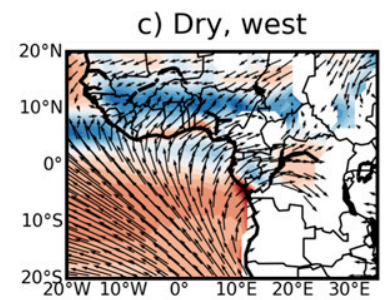

$0.05 \longrightarrow$

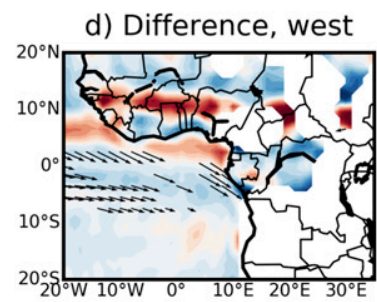

$0.03 \longrightarrow$

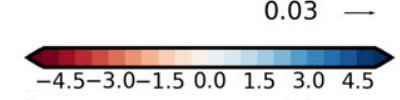

qflux convergence difference

FIG. 10. Long-term mean (1979-2005) SON $q$-flux convergence $\left(10^{-8} \mathrm{~kg} \mathrm{~kg}^{-1} \mathrm{~s}^{-1}\right.$; shaded) and $q$ flux $\left(\mathrm{kg} \mathrm{kg}^{-1} \mathrm{~m} \mathrm{~s}^{-1}\right.$; vectors $)$ at $925 \mathrm{hPa}$ in (a) ERA-I, (b) western Congo wet composite, (c) western Congo dry composite, and (d) wet minus dry difference. Vectors are only shown at grid boxes in (d) when the values in all wet models are greater than the values in all dry models, or all the values in all dry models are greater than the values in all wet models.

$\mathrm{SAH}$ region and rainfall is strong and positive $(r=0.81, p \leq 0.0003)$. Wet models also have a stronger Mascarene high, though the difference in strength is smaller than the SAH. In both oceans, the enhanced high coincides with enhanced southeasterlies to the northeast of the high. In the Atlantic, these recurve into enhanced westerlies at the equator near the African coast. There is a strong, positive correlation between the mean strength of the SAH (averaged between $40^{\circ}$ and $15^{\circ} \mathrm{S}, 40^{\circ} \mathrm{W}$ and $10^{\circ} \mathrm{E}$ ) and the mean westerlies (averaged between $5^{\circ} \mathrm{S}$ and $5^{\circ} \mathrm{N}, 0^{\circ}$ and $20^{\circ} \mathrm{E}$; $r=0.70, p<0.004)$.

Given the known link between equatorial westerlies and the zonal overturning circulation in this region, the overturning circulation over the wider region is shown in Fig. 15. While both wet and dry models feature lowlevel westerly flow, in the wet composite this is part of a well-defined Atlantic-Congo zonally overturning circulation up to $200 \mathrm{hPa}$. Dry models feature a much weaker and less well-defined overturning circulation. The wet minus dry difference plot confirms that the wet composite features both much stronger uplift and subsidence, over the majority of the circulation. Given the lack of significant differences in SST across these composites, this suggests that the driving force for the formation of the overturning circulation is not related to differences in moisture availability, but instead differences in the strength of the dynamical circulation.

Over the Indian Ocean, the differences between wet and dry models are similar to the west composites, though weaker in magnitude. Wet models feature slightly enhanced convection in the eastern Indian Ocean (collocated with a warm SST anomaly), whereas dry models feature stronger convection in the west central Indian Ocean. Again, this means that the region of subsidence over the East African coast is much less developed in dry models, leading to relative wetting there (Fig. 3).

\section{2) MidLEVEl CIRCULATION DIFFERENCES}

Figure 13b suggests that wet and dry models also differ in their representation of the midlevel easterly winds. Wet models show weaker easterlies over the majority of the basin, as well as over the Atlantic. These differences may be due to how the models simulate both the AEJ-N and AEJ-S. Figure 16 shows the latitude-height section of zonal wind in two longitudinal locations; one over the eastern Congo basin, and one over the western Congo basin. In the eastern Congo basin, ERA-I features both a northerly and southerly jet at around $700 \mathrm{hPa}$, with the AEJ-S slightly stronger than the AEJ-N. The wet models also feature a two-jet structure, although the AEJ-S is much weaker. However, dry models do not feature two distinct jets in the mean climatology. Instead, they simulate one region of easterly flow centered slightly north of the equator. This structure is also seen in the individual months of September-November (not shown) and extends farther west with increasing difference between wet and dry models (not shown). The anomalously strong easterlies in dry models are up to $3 \mathrm{~m} \mathrm{~s}^{-1}$ stronger than wet models and ERA-I at the equator.

The difference between wet and dry model jet strength and location can be explained with reference to the meridional gradient in potential temperature (Fig. 17). Dry models feature a stronger and more equatorward peak in meridional potential temperature gradient than in wet models. This collocates well with a more equatorward maximum easterly wind speed at $700 \mathrm{hPa}$.

Differences in jet strength across the basin suggest that in dry models the anomalously strong AEJ may be suppressing rainfall in the region of the upward branch of the overturning circulation seen in Fig. 15. This is discussed in the following section. 


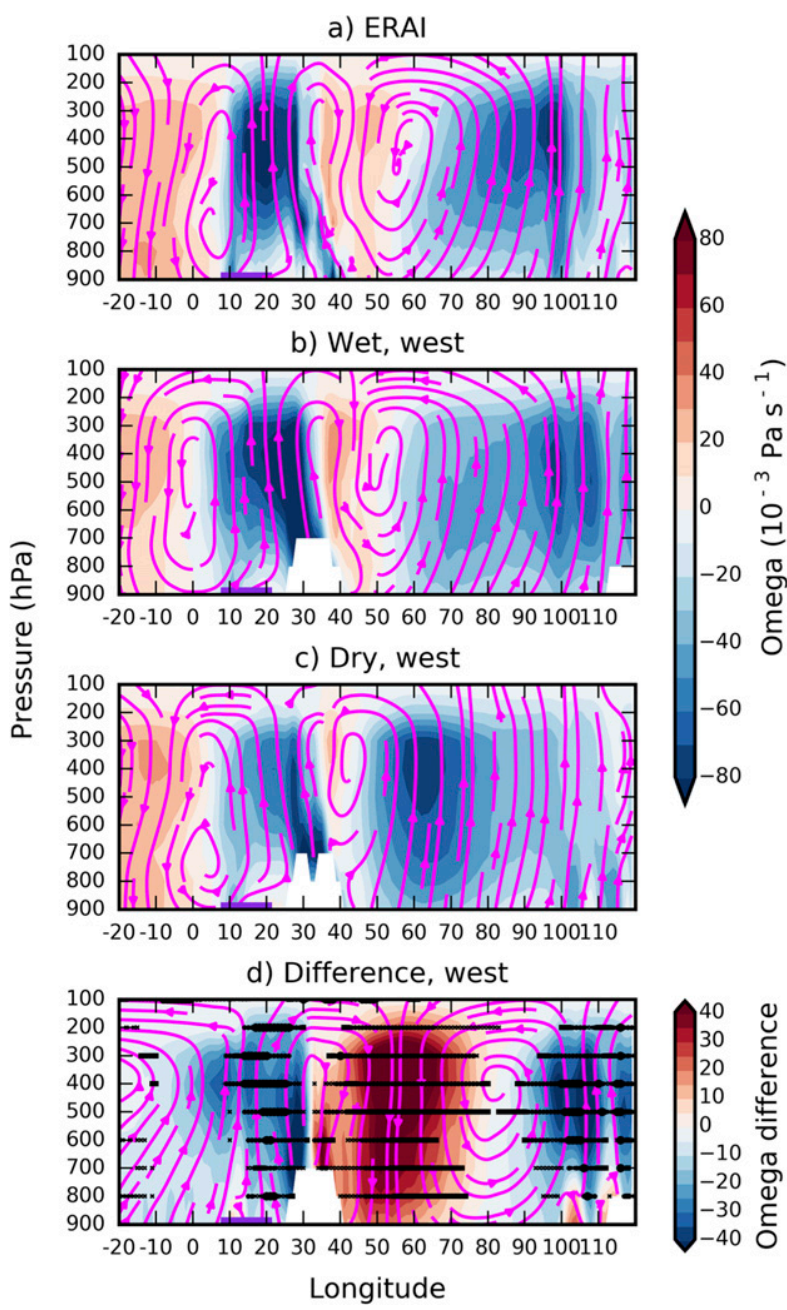

FIG. 11. Long-term mean (1979-2005) SON omega between $3^{\circ} \mathrm{S}$ and $3^{\circ} \mathrm{N}\left(10^{-3} \mathrm{~Pa} \mathrm{~s}^{-1}\right.$; shaded $)$ and divergent component of zonal wind $\left(\mathrm{m} \mathrm{s}^{-1}\right)$ and omega (streamlines) in (a) ERAI, (b) western Congo wet composite, (c) western Congo dry composite, and (d) wet minus dry difference. Stipples are as in Fig. 3. A bilinear interpolation scheme was used to fill missing values to calculate the divergent component of $u$ wind. Areas with high topography in models are masked (white); values below $900 \mathrm{hPa}$ are not shown because of large amounts of topography-related missing data. The purple line shows the extent of the western Congo domain.

\section{Discussion}

\section{a. Rainfall differences between east and west}

There is large variation in mean Congo basin rainfall across models in SON, with some models simulating twice as much rainfall as others. There are also large spatial variations between models, with models tending to feature rainfall maxima in the eastern and western subdomains. These spatial differences have been noted previously (Creese and Washington 2016), but as Fig. 2 shows, they are of particular interest in SON because models with a wet (or dry) west of the basin do not necessarily have a correspondingly wet (or dry) east in this season. This mirrors Dezfuli and Nicholson's (2013) finding that different processes relate to interannual rainfall variability in the east and west of the basin in observational data and suggests that processes relating to model rainfall in each subdomain could be distinct. Our analysis further supports the conclusion that the use of ensemble means as a "best estimate" of the climatology is misleading in the Congo basin (Creese and Washington 2016), as the ensemble shows a rainfall magnitude and distribution not captured by any single model.

Figure 3 also shows that the distinct wet/dry differences in the western and eastern Congo are associated with other nearby rainfall differences. Models that are wetter in the west tend to be drier over the western Indian Ocean and the East African coast than models that are dry in the west. Models that are wetter in the eastern Congo basin also have slightly drier western Indian Oceans, as well as being drier on the Atlantic coast between north Angola and Gabon. This suggests that factors influencing rainfall in the Congo basin often have opposite impacts in these adjacent regions.

\section{b. Influence of SSTs on the west of the basin}

It has long been established that regional climates within Africa are coupled to variations in SSTs in both adjacent and remote oceans. For example, Nicholson and Entekhabi (1987) identified that coastal rainfall in equatorial and southern Africa is suppressed in years with low SST anomalies (SSTAs) and enhanced in years with warm SSTAs, as a result of both direct local forcings and indirect atmospheric mechanisms. Balas et al. (2007) found that rainfall variability is associated with ENSO and the west Indian Ocean in the early part of the year, while in the summer and early fall the Atlantic becomes more important. Previous studies on coupled models have shown that low-level moisture flux across the Atlantic coast is found to be related to model rainfall (Creese and Washington 2016), concurring with studies that show this to be a key region of moisture advection into the Congo in reanalyses (Pokam et al. 2014, 2012). It is also well established that coupled models consistently produce a persistent warm bias in the eastern tropical oceanic regions (Wang et al. 2014).

As a first-order assessment, Atlantic SST biases appear to be one key differentiator between wet and dry models in the west of the basin. Wet models in the west tend to feature a stronger, more northerly, and more persistent bias in the annual cycle than dry models; this is significant in SON across the suite of models $(r=0.67$, $p<0.007)$. The largest difference in western Congo 
a) HadISST2

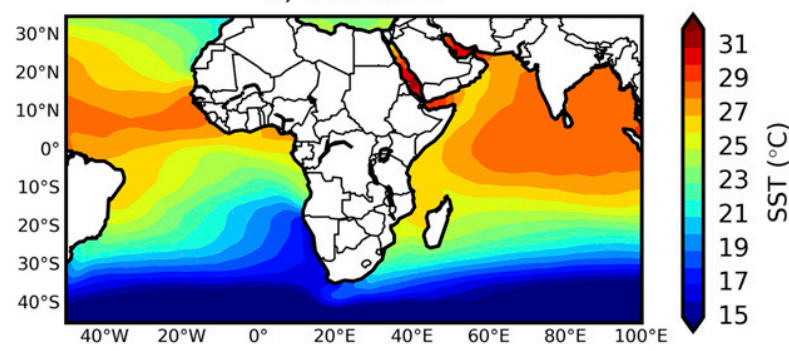

b) Wet models, east

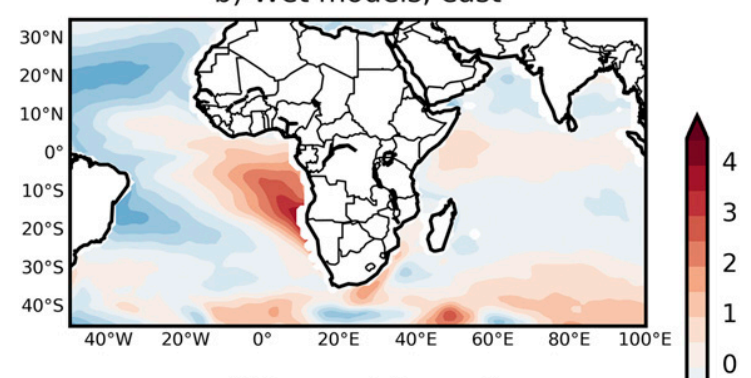

c) Dry models, east

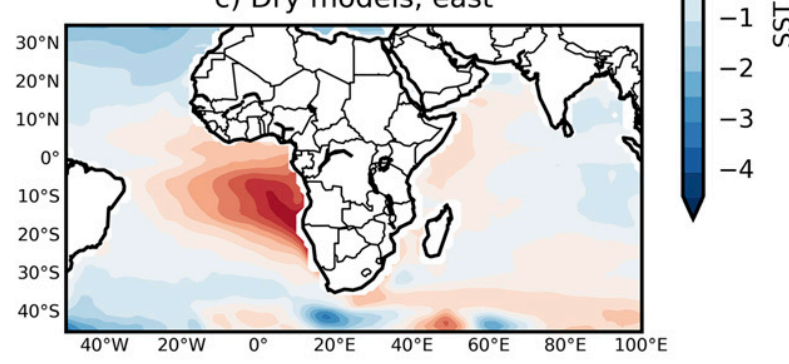

d) Difference, east

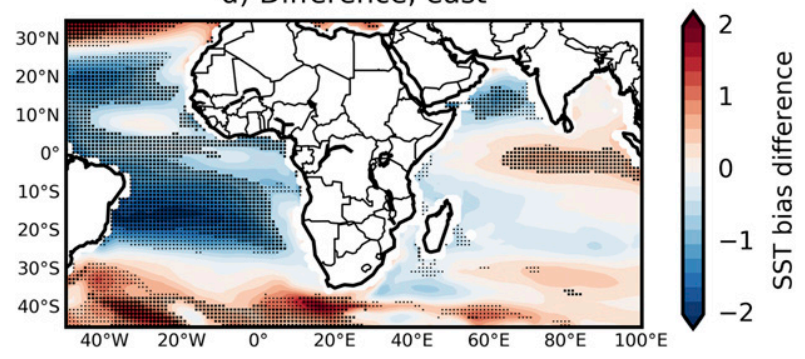

FIG. 12. As in Fig. 7 but for the eastern Congo composites.

basin rainfall between AMIP and CMIP models in the annual cycle also collocates with the peak in the Atlantic SST bias. However, in the east, tropical Atlantic SSTs do not emerge as a significant differentiating factor between the wet and dry composites. Combined with the western subdomain's proximity to the warm bias, this indicates a local process related to SSTs that affects the west but not the east of the basin. Given that we have good SST observations, we can say with certainty there is a misrepresentation of this process in the mean state of these models. This casts doubt on models that are wet in the west of the basin and have a large Atlantic SST bias, as this rainfall can be related to a spurious chain of processes resulting from a known bias in the mean state.

It is interesting to note that the warm/wet relationship found across models is not due to the same "chain" of processes as found in wet and dry year comparisons in reanalysis data. Pokam et al. (2014) and Cook and Vizy (2016) find that years with warm SSTAs are related to enhanced rainfall via a zonal overturning circulation. Cook and Vizy (2016) additionally find that the Atlantic cold tongue and associated land-sea thermal contrast (approximately 2-4K) is necessary to initially set up the overturning circulation. This is not analogous to the relationship found across models in the west, whereby warm SSTAs are associated with enhanced convection over the western Congo basin coast but not corresponding subsidence over the ocean. This is most likely due to the much larger magnitude of coupled model warm biases compared to year-on-year SSTAs in this season. The largest yearly observed SSTA from the mean in the study period is $0.7^{\circ} \mathrm{C}$; positive model biases are on average $1.9^{\circ} \mathrm{C}$ warmer than the observed. This suggests that while the direction of the relationship between Atlantic SSTs and rainfall is the same in both interannual studies and across models, the chain of processes is not, casting further doubt on the credibility of very wet models in the western Congo with large SST biases.

Analysis of the wider region indicates that wet and dry models can also be differentiated by their representation of the Indian Ocean zonal cell. In contrast to the Atlantic cell, wet models are more similar to ERA-I in the Indian Ocean than dry models. Dry models convect much farther westward, away from the warm pool region, and thus feature wetting in the west Indian Ocean where ERA-I and wet models are dry. The down-branch of this circulation is also farther westward, possibly contributing to dampened convection over the western Congo. However, SST biases in the tropical Indian Ocean are relatively small in both composites, and so it is more difficult to determine whether biases are causing the rainfall differences. Further work is needed to assess the plausibility of the link between the Indian Ocean and rainfall in dry models. It may be the case that neither wet, nor dry models represent a plausible future because of different sets of processes, or that either set of models is producing the correct climatology but for the wrong reasons.

\section{c. Dynamical processes affecting the east of the basin}

The processes that are most important for differentiating between wet and dry models in the east of the Congo basin appear to be different from those in the west. Tropical Atlantic SST biases are not found to be a differentiator between wet and dry models in the east 
a) $925 \mathrm{hPa}$

\section{i) ERAI}

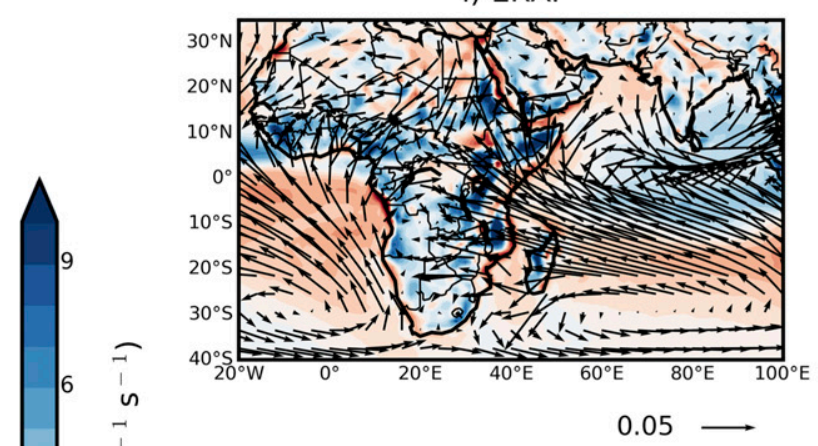

ii) Wet, east

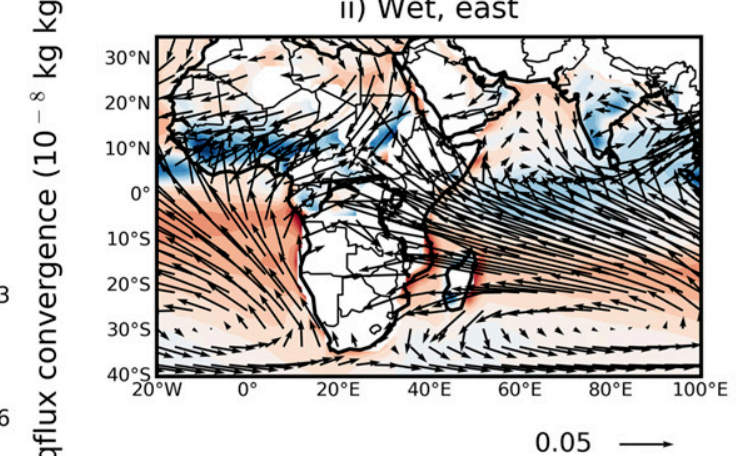

iii) Dry, east

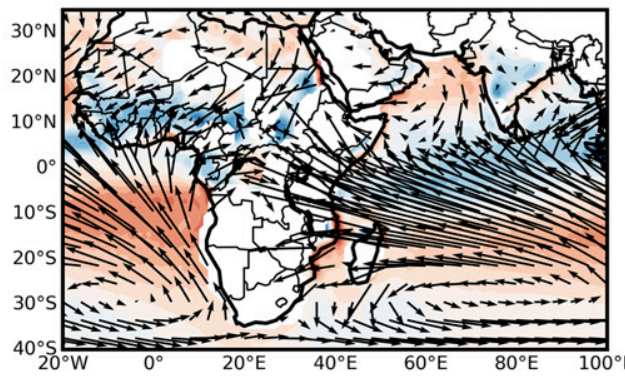

$0.05 \longrightarrow$

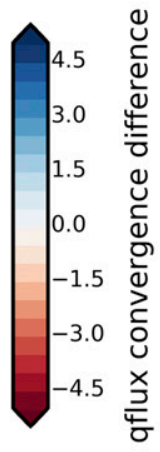

b) $700 \mathrm{hPa}$

i) ERAI

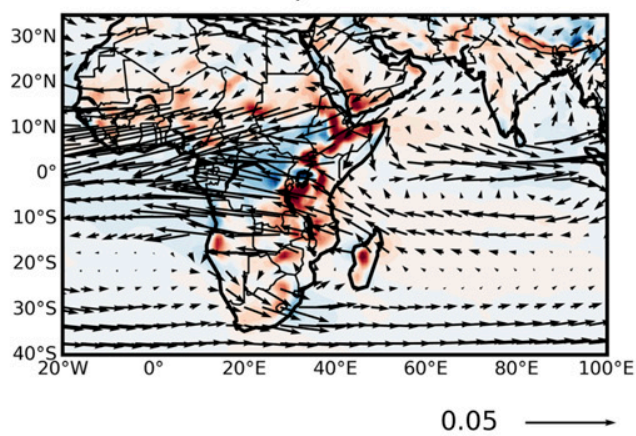

ii) Wet, east

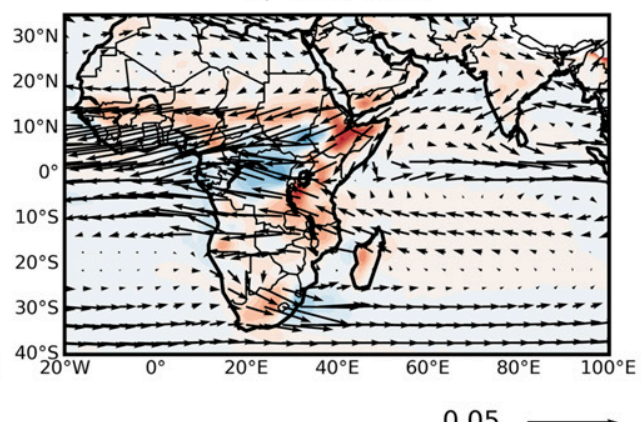

iii) Dry, east

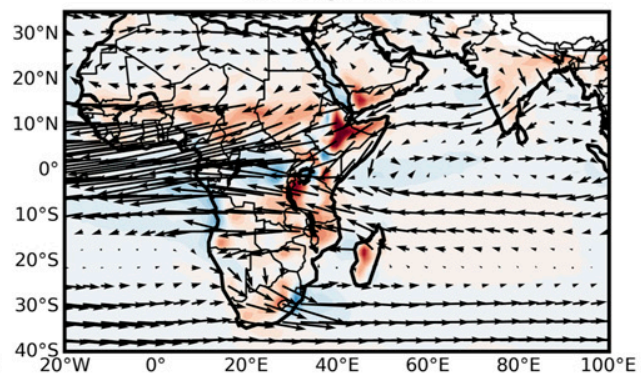

0.05

iv) Difference, east

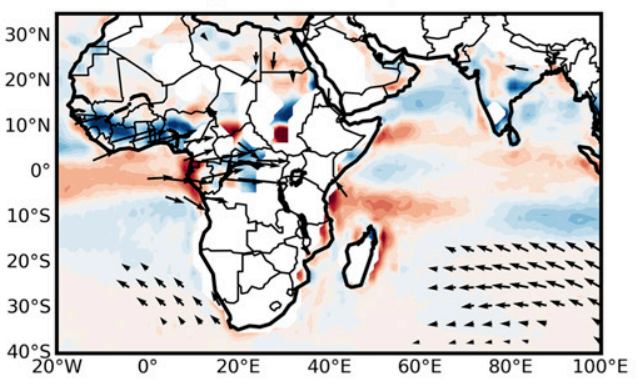

$0.03 \longrightarrow$

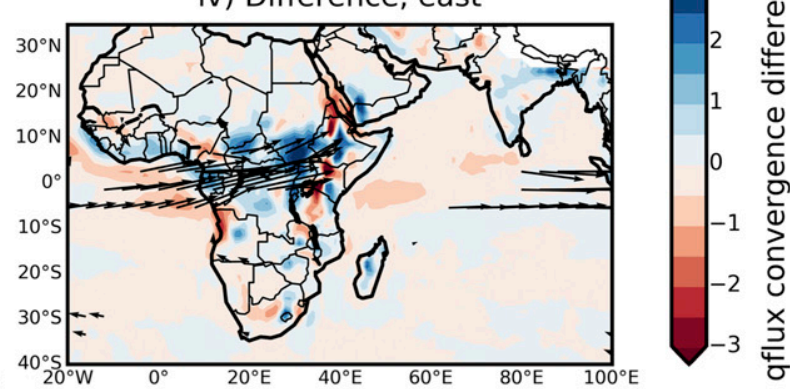

0.03

FIG. 13. Long-term mean (1979-2005) SON $q$-flux convergence $\left(10^{-8} \mathrm{~kg} \mathrm{~kg}^{-1} \mathrm{~s}^{-1}\right.$; shaded) and $q$ flux $\left(\mathrm{kg} \mathrm{kg}^{-1} \mathrm{~m} \mathrm{~s}^{-1}\right.$; vectors) at (a) $925 \mathrm{hPa}$ and (b) $700 \mathrm{hPa}$ in (top) ERA-I, (second row) eastern Congo wet composite, (third row) eastern Congo dry composite, and (bottom) wet minus dry difference. The vectors in the bottom panels are as described in Fig. 10 caption. 


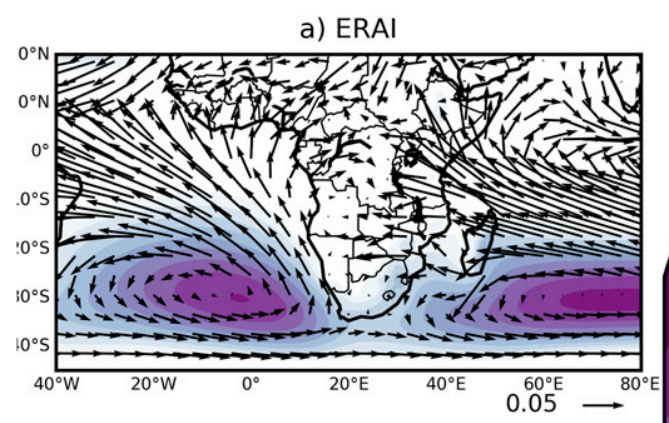

b) Wet models, east

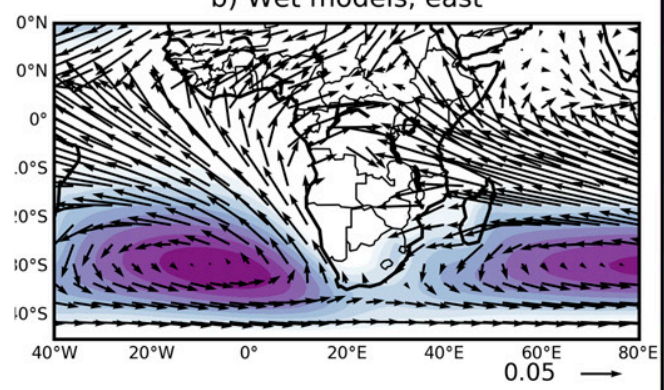

c) Dry models, east

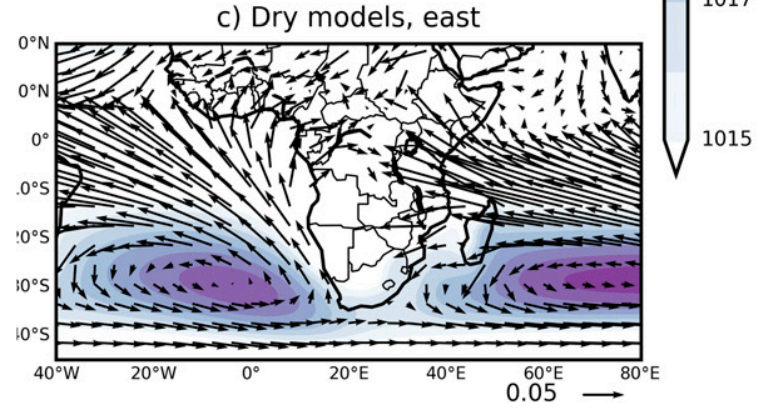

d) Difference, east

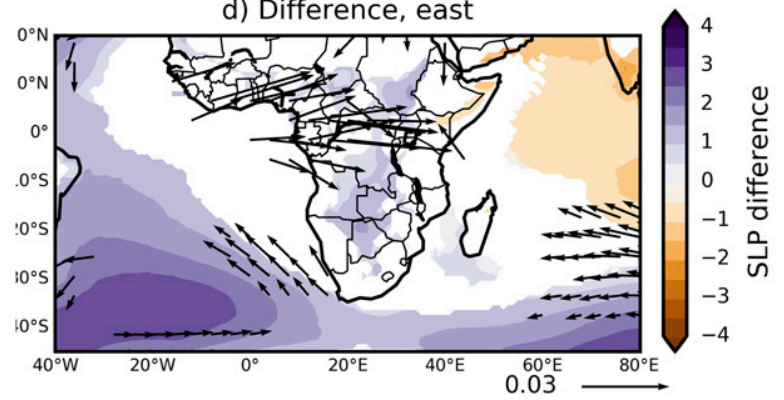

FIG. 14. Mean sea level pressure (hPa; shaded) and $925 \mathrm{hPa} q$ flux ( $\mathrm{kg} \mathrm{kg}^{-1} \mathrm{~m} \mathrm{~s}^{-1}$; vectors), in (a) ERA-I, (b) eastern Congo wet composite, (c) eastern Congo dry composite, and (d) wet minus dry difference. Vectors and MSLP shading are only shown at grid boxes in (d) when the values in all wet models are greater than the values in all dry models, or all the values in all dry models are greater than the values in all wet models.

Congo basin. Instead, the two dominant processes that are identified relate more to the dynamical circulation of the region. These are discussed below.

First, wet models exhibit enhanced low-level westerly flow from the Atlantic, which is positively related to the strength of the southeasterly flow along the northeast flank of the SAH. These southeasterlies then recurve into westerlies at the equator. This flow is divergent (i.e., accelerates) over the Atlantic coast, where wet/east models are drier (Fig. 3), and penetrates far into the continent to the east of the basin. This low-level westerly flow constitutes the lower branch of an Atlantic-Congo overturning circulation, which is stronger in wet models than dry models, and which has an enhanced upward branch over the east and central Congo. This cell is also linked to an overturning cell in the Indian Ocean, which has greater subsidence at the East African coast in wet models. The enhanced SAH may also be linked to the relatively cold SSTs in the South Atlantic in wet models compared to dry models. It is important to note that this analysis cannot determine cause and effect; the enhanced convection over the Congo is itself likely to contribute to stronger subtropical highs via an enhanced Hadley circulation.

In addition to the likely local influence of the SAH on the strength of the westerlies, and thus convection over the eastern Congo, Fig. 14 suggests the contrast between relatively high pressures in the subtropical South Atlantic and low pressures in the Indian Ocean could also play a role in enhancing westerly flow via an enhanced pressure gradient. Dezfuli et al. (2015) identified a similar mechanism that differentiates between wet and dry years in the southeastern Congo between December and March. In their analysis, wet years featured anomalously high pressure over the tropical Atlantic and anomalously low pressure over the southwest Indian Ocean, contributing to enhanced flow into the eastern part of south equatorial Africa.

The second process identified as important for differentiating between wet and dry models is model representation of the midlevel AEJs. Dry models have much stronger and more equatorward AEJs, which may contribute to suppressed rainfall in the region of the upward branch of the overturning circulation over the central Congo basin. Jackson et al.'s (2009) analysis suggests that a stronger AEJ-S may actually enhance rainfall, as low-level convergence is encouraged at the right side of the jet entrance that lies over the basin. However, the dry models' tendency to merge the two jets with a core near the equator may suppress this activity, as the Coriolis influence is small in proximity to the equator. Indeed, at both $700 \mathrm{hPa}$ (Fig. 13b) and $600 \mathrm{hPa}$ (not shown), dry models feature anomalous divergence across the basin compared to wet models. The negative relationship between rainfall and AEJ strength has also been found in observational data in this region, whereby dry years feature stronger midlevel easterlies than wet years, associated with anomalous subsidence throughout the column (Dezfuli and Nicholson 2013). This analysis suggests that the combination of stronger low-level westerlies and weaker midlevel easterlies allows for the formation of a 


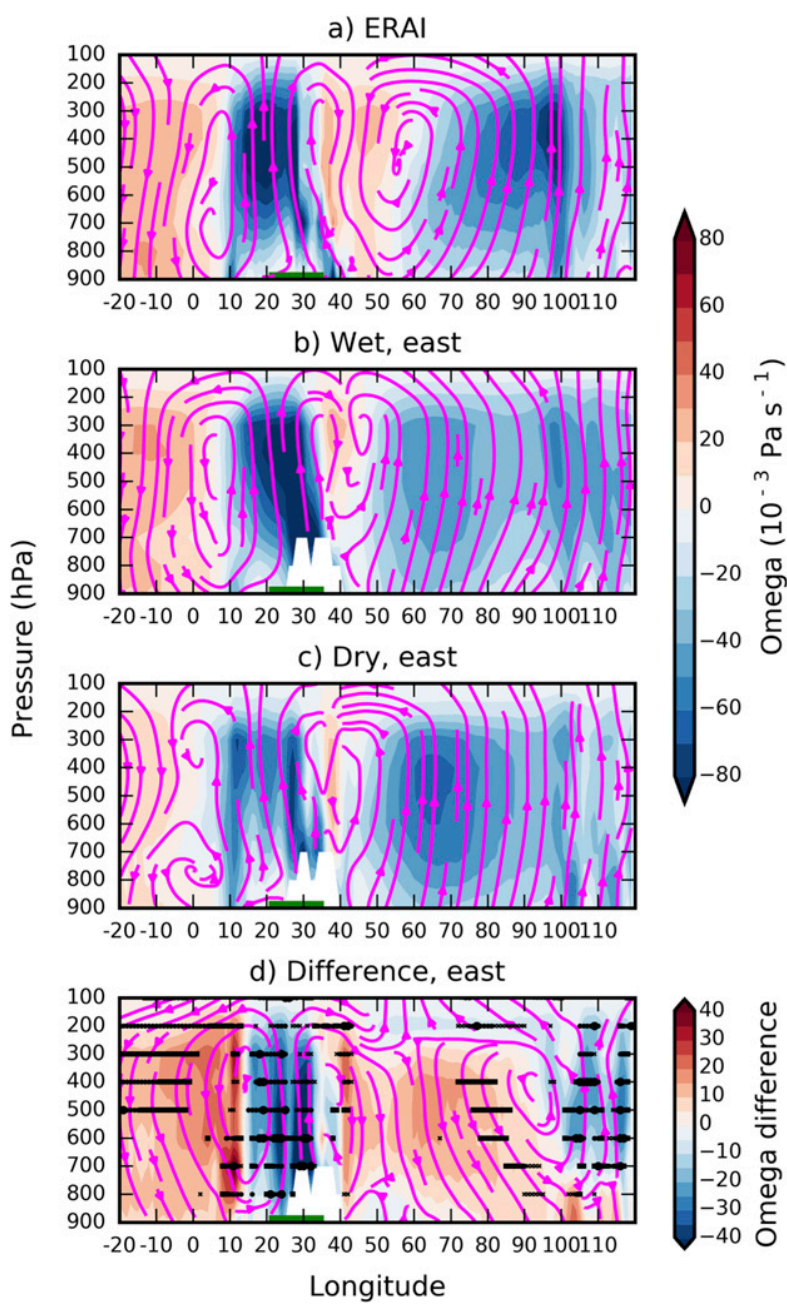

FIG. 15. As in Fig. 11 but for eastern Congo composites. The green line shows the extent of the eastern Congo basin domain.

stronger overturning circulation in wet models, enhancing convection over the eastern subdomain of the Congo.

As before, it is interesting to note that the chain of processes relating to rainfall are not the same across models as between years in interannual data. First, the strength of the low-level westerlies appears to be dominated by different processes in models and observations. While some studies have suggested that the formation of equatorial westerlies is associated predominantly with the surface pressure gradient associated with the SAH (e.g., Nicholson and Grist 2003), Pokam et al. (2014) suggest that when they recurve into southwesterlies, their strength is driven by the land-sea thermal contrast near the equator. However, in models, the land-sea contrast is significantly weakened because of the large SST biases in the equatorial Atlantic, and the difference in strength of both the southeasterlies and westerlies appears to be related to the strength of the SAH. Second, while both wet models and wet years in reanalysis feature enhanced overturning circulations, the mechanisms responsible for setting up and driving this circulation are not the same. Cook and Vizy's (2016) analysis found that a strong overturning circulation, and associated increase in rainfall, is related to anomalously warm SST biases, as they contribute to enhanced moisture flux into the region. This study instead finds that an anomalously strong low-level westerly flow in wet models is the main differentiating factor, as SST differences are negligible. Therefore, while observational studies of interannual variability are a good starting point for determining the processes likely to influence relative rainfall in models, in this instance they are not a complete analog for how models behave.

\section{Summary}

This study uses a process-based methodology to try to determine some of the processes related to model rainfall in SON in the Congo basin. Mean rainfall in SON can differ by as much as a factor of 3 among CMIP5 models, and models feature large differences in rainfall distribution. Rainfall in the west and east of the basin is not correlated across models in SON; that is, models that are wet in the west are not necessarily wet in the east, whereas in most months, western and eastern rainfall are positively correlated. This suggests that distinct processes may be the dominant influences on rainfall in each half of the basin in SON.

Wet models in the west of the basin tend to have a stronger warm SST bias in the tropical eastern Atlantic than dry models. A proposed chain of processes in the west is as follows:

1) Wet models tend to have higher SST biases in the Gulf of Guinea.

2) This enhances evaporation at the coast.

3) Enhanced evaporation contributes to a local enhancement of convection and thus rainfall on the western Congo coast.

Enhanced rainfall in the west is also linked to a stronger Indian Ocean overturning cell, which may in turn be related to anomalously warm SSTs in the eastern Indian Ocean. However, this SST link is less obvious than in the tropical Atlantic, and more work is needed to establish the plausibility of this mechanism.

Model wetness in the east of the basin is unrelated to the strength of Atlantic SST warm biases and appears to be more related to dynamical processes. A proposed chain of processes in the east is as follows:

1) Wet models have significantly stronger low-level westerlies across the tropical eastern Atlantic, related to the strength of the South Atlantic high. 

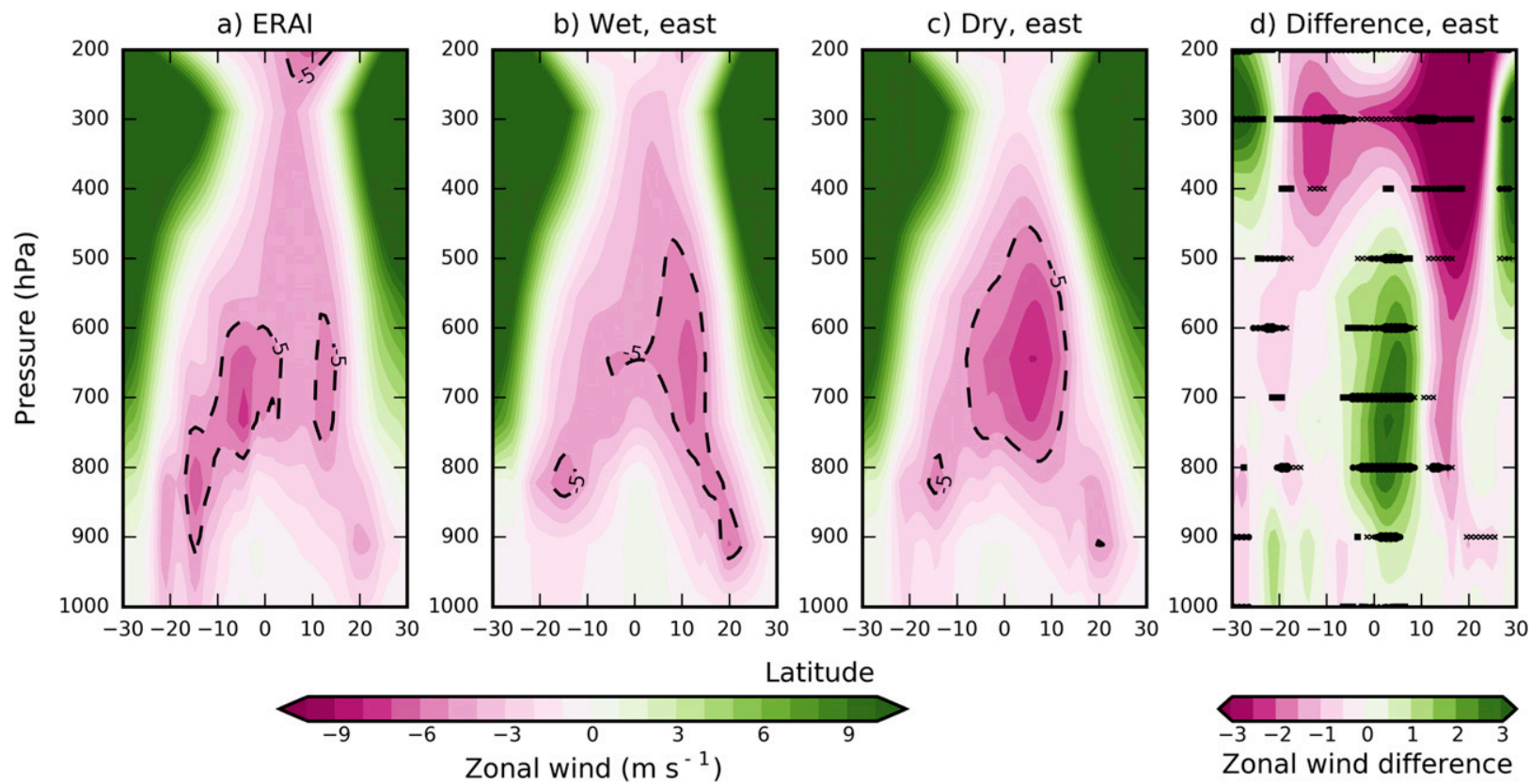

FIG. 16. Latitude-height cross section of zonal wind averaged across $26^{\circ}-30^{\circ} \mathrm{E}\left(\mathrm{m} \mathrm{s}^{-1}\right.$; shaded) and location of $-5 \mathrm{~m} \mathrm{~s}^{-1}$ contour (dashed line) in (a) ERA-I, (b) eastern Congo wet composite, (c) eastern Congo dry composite, and (d) wet minus dry difference. Stipples in (d) are as in Fig. 3.

2) This flow is more divergent at the Atlantic coast in wet models and penetrates farther inland to the eastern Congo basin.

3) The stronger LLWs form the lower branch of an enhanced zonally overturning circulation, which contributes to greater moisture advection into and greater uplift over the eastern Congo basin.

4) A stronger Indian Ocean overturning cell may also contribute to greater subsidence over the western Indian Ocean and greater convection over the eastern Congo basin.

5) Wet models have a weaker and more poleward AEJ-N, whereas the stronger and more equatorward AEJ-N in dry models may contribute to disrupting the overturning circulation and suppress rainfall.

a) ERAI

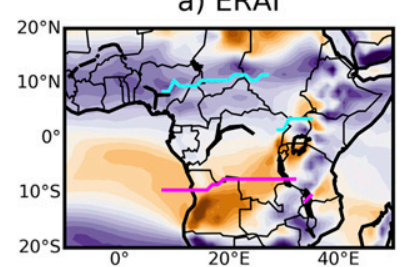

b) Wet, east

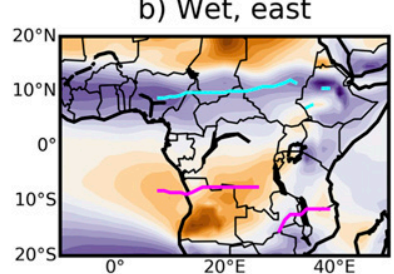

This assessment questions the credibility of models that are very wet in the west of the Congo where they are associated with a large Atlantic SST bias. However, this does not necessarily mean that dry models are more plausible; this analysis suggests that dry models feature a significantly different Indian Ocean overturning cell, and further work is needed to establish the plausibility of this. Further work is needed to assess the credibility of rainfall-producing processes in coupled models in the eastern Congo basin because of the presence of several processes with combined effects.

Acknowledgments. The GCM data used in this study were made available through the Earth System Grid Federation (ESGF) Peer-to-Peer system (https://pcmdi.

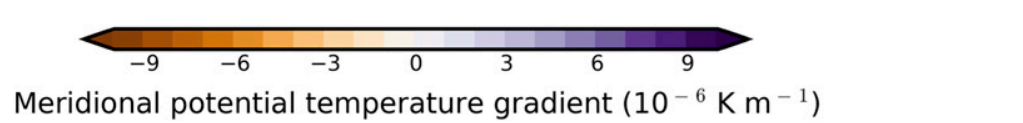

c) Dry, east

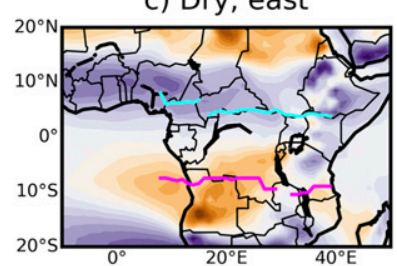

d) Difference, east

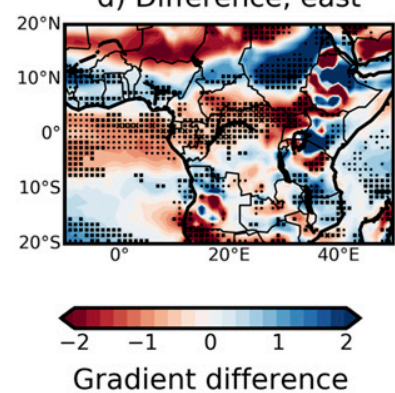

FIG. 17. Long-term mean (1979-2005) meridional potential temperature gradient $\left(10^{-6} \mathrm{~K} \mathrm{~m}^{-1}\right.$; shaded) at $850 \mathrm{hPa}$ in (a) ERA-I, (b) eastern Congo wet composite, (c) eastern Congo dry composite, and (d) wet minus dry difference. Lines show latitudinal location of maximum easterly wind $\left(\leq-5 \mathrm{~m} \mathrm{~s}^{-1}\right)$ speed at $700 \mathrm{hPa}$ in region of AEJ-N (cyan) and AEJ-S (magenta). Stipples in (d) are as in Fig. 3. 
llnl.gov/search/cmip5/). We also acknowledge NOAA/ OAR/ESRL PSD and ECMWF for making available the NCEP and ERA-I datasets. The first author is fully funded by the U.K. Natural Environmental Research Council (NERC) via a Doctoral Training Programme (Grant NE/L002612/1), and partly funded by a Met Office CASE studentship. Richard Washington is partly supported by NERC and the U.K. Government's Department for International Development (DfID) UMFULA project (NE/M020207/1). The authors acknowledge the helpful inputs of Callum Munday, Dr. Rachel James, and Dr. Neil Hart, and thank the two reviewers for their constructive comments on the manuscript.

\section{REFERENCES}

Balas, N., S. E. Nicholson, and D. Klotter, 2007: The relationship of rainfall variability in west central Africa to sea-surface temperature fluctuation. Int. J. Climatol., 27, 1335-1349, https:// doi.org/10.1002/joc.1456.

Bentsen, M., and Coauthors, 2013: The Norwegian Earth System Model, NorESM1-M-Part 1: Description and basic evaluation of the physical climate. Geosci. Model Dev., 6, 687-720, https://doi.org/10.5194/gmd-6-687-2013.

Biasutti, M., A. H. Sobel, and S. J. Camargo, 2009: The role of the Sahara low in summertime Sahel rainfall variability and change in the CMIP3 models. J. Climate, 22, 5755-5771, https://doi.org/10.1175/2009JCLI2969.1.

Black, E., J. Slingo, and K. R. Sperber, 2003: An observational study of the relationship between excessively strong short rains in coastal East Africa and Indian Ocean SST. Mon. Wea. Rev., 131, 74-94, https://doi.org/10.1175/1520-0493(2003)131<0074: AOSOTR $>2.0 . \mathrm{CO} ; 2$.

Blamey, R. C., and C. J. C. Reason, 2012: Mesoscale convective complexes over southern Africa. J. Climate, 25, 753-766, https://doi.org/10.1175/JCLI-D-10-05013.1.

Bollasina, M. A., and Y. Ming, 2013: The general circulation model precipitation bias over the southwestern equatorial Indian Ocean and its implications for simulating the South Asian monsoon. Climate Dyn., 40, 823-838, https://doi.org/10.1007/ s00382-012-1347-7.

Camberlin, P., and R. E. Okoola, 2003: The onset and cessation of the "long rains" in eastern Africa and their interannual variability. Theor. Appl. Climatol., 54, 43-54, https://oi.org/ 10.1007/s00704-002-0721-5.

Collier, M., and P. Uhe, 2012: CMIP5 datasets from the ACCESS1.0 and ACCESS1.3 coupled climate models. Centre for Australian Weather and Climate Research Tech. Rep. 059, 25 pp.

Cook, K. H., and E. K. Vizy, 2006: Coupled model simulations of the West African monsoon system: Twentieth- and twenty-firstcentury simulations. J. Climate, 19, 3681-3703, https://doi org/10.1175/JCLI3814.1.

—, and - 2016: The Congo basin Walker circulation: Dynamics and connections to precipitation. Climate Dyn., 47, 697-717, https://doi.org/10.1007/s00382-015-2864-y.

Creese, A., and R. Washington, 2016: Using qflux to constrain modeled Congo basin rainfall in the CMIP5 ensemble. J. Geophys. Res. Atmos., 121, 13 415-13 442, https://doi.org/ 10.1002/2016JD025596.

Dargie, G. C., S. L. Lewis, I. T. Lawson, E. T. A. Mitchard, S. E. Page, Y. E. Bocko, and S. A. Ifo, 2017: Age, extent and carbon storage of the central Congo basin peatland complex. Nature, 542, 86-90, https://doi.org/10.1038/nature21048.

Dee, D. P., and Coauthors, 2011: The ERA-Interim reanalysis: Configuration and performance of the data assimilation system. Quart. J. Roy. Meteor. Soc., 137, 553-597, https://doi.org/ 10.1002/qj.828.

Dezfuli, A., 2017: Climate of western and central equatorial Africa. Oxford Research Encyclopedia of Climate Science, 46 pp., https://doi.org/10.1093/acrefore/9780190228620.013.511.

, and S. E. Nicholson, 2013: The relationship of rainfall variability in western equatorial Africa to the tropical oceans and atmospheric circulation. Part II: The boreal autumn. J. Climate, 26, 66-84, https://doi.org/10.1175/JCLI-D-11-00686.1.

_ B. F. Zaitchik, and A. Gnanadesikan, 2015: Regional atmospheric circulation and rainfall variability in south equatorial Africa. J. Climate, 28, 809-818, https://doi.org/10.1175/ JCLI-D-14-00333.1.

Dieppois, B., M. Rouault, and M. New, 2015: The impact of ENSO on southern African rainfall in CMIP5 ocean atmosphere coupled climate models. Climate Dyn., 45, 2425-2442, https:// doi.org/10.1007/s00382-015-2480-x.

Donner, L. J., and Coauthors, 2011: The dynamical core, physical parameterizations, and basic simulation characteristics of the atmospheric component AM3 of the GFDL global coupled model CM3. J. Climate, 24, 3484-3519, https://doi.org/10.1175/ 2011JCLI3955.1.

Dufresne, J.-L., and Coauthors, 2013: Climate change projections using the IPSL-CM5 Earth System Model: From CMIP3 to CMIP5. Climate Dyn., 40, 2123-2165, https://doi.org/10.1007/ s00382-012-1636-1.

Dyer, E. L. E., D. B. A. Jones, J. Nusbaumer, H. Li, O. Collins, G. Vettoretti, and D. Noone, 2017: Congo basin precipitation: Assessing seasonality, regional interactions, and sources of moisture. J. Geophys. Res. Atmos., 122, 6882-6898, https://doi.org/ 10.1002/2016JD026240.

Eichhorn, A., and J. Bader, 2017: Impact of tropical Atlantic seasurface temperature biases on the simulated atmospheric circulation and precipitation over the Atlantic region: An ECHAM6 model study. Climate Dyn., 49, 2061-2075, https:// doi.org/10.1007/s00382-016-3415-x.

Folland, C. K., T. N. Palmer, and D. E. Parker, 1986: Sahel rainfall and worldwide sea temperatures, 1901-85. Nature, 320, 602607, https://doi.org/10.1038/320602a0.

Fontaine, B., S. Janicot, and V. Moron, 1995: Rainfall anomaly patterns and wind field signals over West Africa in August (1958-1989). J. Climate, 8, 1503-1510, https://doi.org/10.1175/ 1520-0442(1995)008<1503:RAPAWF >2.0.CO;2.

Gent, P. R., and Coauthors, 2011: The Community Climate System Model version 4. J. Climate, 24, 4973-4991, https://doi.org/ 10.1175/2011JCLI4083.1.

Grist, J. P., and S. E. Nicholson, 2001: A study of the dynamic factors influencing the rainfall variability in the West African Sahel. J. Climate, 14, 1337-1359, https://doi.org/10.1175/ 1520-0442(2001)014<1337:ASOTDF>2.0.CO;2.

Haensler, A., F. Saeed, and D. Jacob, 2013: Assessing the robustness of projected precipitation changes over central Africa on the basis of a multitude of global and regional climate projections. Climatic Change, 121, 349-363, https://doi.org/ 10.1007/s10584-013-0863-8.

Harris, I., P. D. Jones, T. J. Osborn, and D. H. Lister, 2014: Updated high-resolution grids of monthly climatic observationsThe CRU TS3.10 dataset. Int. J. Climatol., 34, 623-642, https:// doi.org/10.1002/joc.3711. 
Hart, N. C. G., C. J. C. Reason, and N. Fauchereau, 2013: Cloud bands over southern Africa: Seasonality, contribution to rainfall variability and modulation by the MJO. Climate Dyn., 41, 1199-1212, https://doi.org/10.1007/ s00382-012-1589-4.

Hastenrath, S., 2000: Zonal circulations over the equatorial Indian Ocean. J. Climate, 13, 2746-2756, https://doi.org/10.1175/ 1520-0442(2000)013<2746:ZCOTEI $>2.0$.CO;2.

Hazeleger, W., and Coauthors, 2010: EC-Earth: A seamless Earthsystem prediction approach in action. Bull. Amer. Meteor. Soc., 91, 1357-1364, https://doi.org/10.1175/2010BAMS2877.1.

Hirons, L., and A. Turner, 2018: The impact of Indian Ocean meanstate biases on the representation of the East African short rains. J. Climate, https://doi.org/10.1175/JCLI-D-17-0804.1, in press.

Hoerling, M., J. Hurrell, J. Eischeid, and A. Phillips, 2006: Detection and attribution of twentieth-century northern and southern African rainfall change. J. Climate, 19, 3989-4008, https://doi.org/10.1175/JCLI3842.1.

Huffman, G. J., and Coauthors, 2007: The TRMM Multisatellite Precipitation Analysis (TMPA): Quasi-global, multiyear, combined-sensor precipitation estimates at fine scales. J. Hydrometeor., 8, 38-55, https://doi.org/10.1175/JHM560.1.

Jackson, B., S. E. Nicholson, and D. Klotter, 2009: Mesoscale convective systems over western equatorial Africa and their relationship to large-scale circulation. Mon. Wea. Rev., 137, 1272-1294, https://doi.org/10.1175/2008MWR2525.1.

James, R., R. Washington, and R. Jones, 2015: Process-based assessment of an ensemble of climate projections for West Africa. J. Geophys. Res. Atmos., 120, 1221-1238, https://doi.org/ 10.1002/2014JD022513.

— , and Coauthors, 2018: Evaluating climate models with an African lens. Bull. Amer. Meteor. Soc., 99, 313-336, https://doi.org/ 10.1175/BAMS-D-16-0090.1.

Jeffrey, S., L. Rotstayn, M. Collier, S. Dravitzki, C. Hamalainen, C. Moeseneder, K. Wong, and J. Syktus, 2013: Australia's CMIP5 submission using the CSIRO-Mk3.6 model. Aust. Meteor. Oceanogr. J., 63, 1-13, https://doi.org/10.22499/2.6301.001.

Jones, C. D., and Coauthors, 2011: The HadGEM2-ES implementation of CMIP5 centennial simulations. Geosci. Model Dev., 4, 543-570, https://doi.org/10.5194/gmd-4-543-2011.

Joseph, S., A. K. Sahai, B. N. Goswami, P. Terray, S. Masson, and J.-J. Luo, 2012: Possible role of warm SST bias in the simulation of boreal summer monsoon in SINTEX-F2 coupled model. Climate Dyn., 38, 1561-1576, https://doi.org/10.1007/s00382-011-1264-1.

Jury, M. R., E. Matari, and M. Matitu, 2009: Equatorial African climate teleconnections. Theor. Appl. Climatol., 95, 407-416, https://doi.org/10.1007/s00704-008-0018-4.

Kalnay, E., and Coauthors, 1996: The NCEP/NCAR 40-Year Reanalysis Project. Bull. Amer. Meteor. Soc., 77, 437-471, https:// doi.org/10.1175/1520-0477(1996)077<0437:TNYRP>2.0.CO;2.

Kanamitsu, M., and T. N. Krishnamurti, 1978: Northern summer tropical circulations during drought and normal rainfall months. Mon. Wea. Rev., 106, 331-347, https://doi.org/10.1175/ 1520-0493(1978)106<0331:NSTCDD>2.0.CO;2.

Large, W. G., and G. Danabasoglu, 2006: Attribution and impacts of upper-ocean biases in CCSM3. J. Climate, 19, 2325-2346, https://doi.org/10.1175/JCLI3740.1.

Lazenby, M. J., M. C. Todd, and Y. Wang, 2016: Climate model simulation of the south Indian Ocean convergence zone: Mean state and variability. Climate Res., 68, 59-71, https://doi.org/ $10.3354 / \mathrm{cr} 01382$.

Li, L., and Coauthors, 2013: The Flexible Global OceanAtmosphere-Land System Model, grid-point version 2:
FGOALS-g2. Adv. Atmos. Sci., 30, 543-560, https://doi.org/ 10.1007/s00376-012-2140-6.

Liebmann, B., and Coauthors, 2014: Understanding recent eastern Horn of Africa rainfall variability and change. J. Climate, 27, 8630-8645, https://doi.org/10.1175/JCLI-D-13-00714.1.

Lyon, B., and D. G. DeWitt, 2012: A recent and abrupt decline in the East African long rains. Geophys. Res. Lett., 39, L02702, https://doi.org/10.1029/2011GL050337.

Marsland, S. J., H. Haak, J. H. Jungclaus, M. Latif, and F. Röske, 2003: The Max-Planck-Institute global ocean/sea ice model with orthogonal curvilinear coordinates. Ocean Modell., 5, 91127, https://doi.org/10.1016/S1463-5003(02)00015-X.

Munday, C., and R. Washington, 2017: Circulation controls on southern African precipitation in coupled models: The role of the Angola low. J. Geophys. Res. Atmos., 122, 861-877, https:// doi.org/10.1002/2016JD025736.

Neale, R. B., and Coauthors, 2012: Description of the NCAR Community Atmosphere Model (CAM 5.0). NCAR Tech. Note NCAR/TN-486+STR, 268 pp., http://www.cesm.ucar.edu/ models/cesm1.2/cam/docs/description/cam5_desc.pdf.

Newell, R. E., and J. W. Kidson, 1984: African mean wind changes between Sahelian wet and dry periods. J. Climatol., 4, 27-33, https://doi.org/10.1002/joc.3370040103.

Niang, I., and Coauthors, 2014: Africa. Climate Change 2014: Impacts, Adaptation, and Vulnerability. Part B: Regional Aspects. Cambridge University Press, 1199-1265, http://www.ipcc.ch/ pdf/assessment-report/ar5/wg2/WGIIAR5-Chap22_FINAL.pdf.

Nicholson, S. E., 1980: The nature of rainfall fluctuations in subtropical West Africa. Mon. Wea. Rev., 108, 473-487, https://doi.org/ 10.1175/1520-0493(1980)108<0473:TNORFI > 2.0.CO;2.

_ 2017: Climate and climatic variability of rainfall over eastern Africa. Rev. Geophys., 55, 590-635, https://doi.org/10.1002/ 2016RG000544.

— , and D. Entekhabi, 1987: Rainfall variability in equatorial and southern Africa: Relationships with sea surface temperatures along the southwestern coast of Africa. J. Climate Appl. Meteor., 26, 561-578, https://doi.org/10.1175/1520-0450(1987)026<0561: RVIEAS $>2.0 . \mathrm{CO} ; 2$.

- - , and J. P. Grist, 2003: The seasonal evolution of the atmospheric circulation over West Africa and equatorial Africa. J. Climate, 16, 1013-1030, https://doi.org/10.1175/ 1520-0442(2003)016<1013:TSEOTA >2.0.CO;2.

— , and A. K. Dezfuli, 2013: The relationship of rainfall variability in western equatorial Africa to the tropical oceans and atmospheric circulation. Part I: The boreal spring. J. Climate, 26, 45-65, https://doi.org/10.1175/JCLI-D-11-00653.1.

Pokam, W. M., L. A. Tchotchou Djiotang, and F. K. Mkankam, 2012: Atmospheric water vapor transport and recycling in equatorial central Africa through NCEP/NCAR reanalysis data. Climate Dyn., 38, 1715-1729, https://doi.org/10.1007/ s00382-011-1242-7.

- C. L. Bain, R. S. Chadwick, R. Graham, D. J. Sonwa, and F. M. Kamga, 2014: Identification of processes driving lowlevel westerlies in west equatorial Africa. J. Climate, 27, 42454262, https://doi.org/10.1175/JCLI-D-13-00490.1.

Pomposi, C., Y. Kushnir, and A. Giannini, 2015: Moisture budget analysis of SST-driven decadal Sahel precipitation variability in the twentieth century. Climate Dyn., 44, 3303-3321, https:// doi.org/10.1007/s00382-014-2382-3.

Prodhomme, C., P. Terray, S. Masson, T. Izumo, T. Tozuka, and T. Yamagata, 2014: Impacts of Indian Ocean SST biases on the Indian monsoon: As simulated in a global coupled model. Climate Dyn., 42, 271-290, https://doi.org/10.1007/s00382-013-1671-6. 
Reason, C. J. C., and H. Mulenga, 1999: Relationships between South African rainfall and SST anomalies in the southwest Indian Ocean. Int. J. Climatol., 19, 1651-1673, https://doi.org/10.1002/(SICI)1097-0088(199912)19:15<1651:: AID-JOC439>3.0.CO;2-U.

Richter, I., 2015: Climate model biases in the eastern tropical oceans: Causes, impacts and ways forward. Wiley Interdiscip. Rev.: Climate Change, 6, 345-358, https://doi.org/10.1002/wcc.338.

—, S.-P. Xie, A. T. Wittenberg, and Y. Masumoto, 2012: Tropical Atlantic biases and their relation to surface wind stress and terrestrial precipitation. Climate Dyn., 38, 985-1001, https:// doi.org/10.1007/s00382-011-1038-9.

_ the tropics. Indo-Pacific Climate Variability and Predictability, S. K. Behera and T. Yamagata, Eds., World Scientific, 213-263.

Rowell, D. P., B. B. B. Booth, S. E. Nicholson, and P. Good, 2015: Reconciling past and future rainfall trends over East Africa. J. Climate, 28, 9768-9788, https://doi.org/10.1175/ JCLI-D-15-0140.1.

Sandjon, A. T., A. Nzeukou, and C. Tchawoua, 2012: Intraseasonal atmospheric variability and its interannual modulation in central Africa. Meteor. Atmos. Phys., 117, 167-179, https://doi.org/ 10.1007/s00703-012-0196-6

Schmidt, G. A., and Coauthors, 2014: Configuration and assessment of the GISS ModelE2 contributions to the CMIP5 archive. J. Adv. Model. Earth Syst., 6, 141-184, https://doi.org/ 10.1002/2013MS000265.

Schneider, U., A. Becker, P. Finger, A. Meyer-Christoffer, B. Rudolf, and M. Ziese, 2015: GPCC full data reanalysis at $0.5^{\circ}$ : Monthly land-surface precipitation from rain-gauges built on GTS-based and historic data, version 7.0. GPCC, accessed 19 May 2016, https://doi.org/10.5676/DWD_GPCC/ FD_M_V7_050.

Scoccimarro, E., and Coauthors, 2011: Effects of tropical cyclones on ocean heat transport in a high-resolution coupled general circulation model. J. Climate, 24, 4368-4384, https://doi.org/ 10.1175/2011JCLI4104.1.

Sorí, R., R. Nieto, S. M. Vicente-Serrano, A. Drumond, and L. Gimeno, 2017: A Lagrangian perspective of the hydrological cycle in the Congo River basin. Earth Syst. Dyn., 8, 653 675, https://doi.org/10.5194/esd-8-653-2017.

Sun, Q., C. Miao, Q. Duan, H. Ashouri, S. Sorooshian, and K.-L. Hsu, 2018: A review of global precipitation datasets: Data sources, estimation, and intercomparisons. Rev. Geophys., 56, 79-107, https://doi.org/10.1002/2017RG000574.

Taylor, K. E., R. J. Stouffer, and G. A. Meehl, 2012: An overview of CMIP5 and the experiment design. Bull. Amer. Meteor. Soc., 93, 485-498, https://doi.org/10.1175/BAMS-D-11-00094.1.

Tierney, J. E., C. C. Ummenhofer, and P. B. deMenocal, 2015: Past and future rainfall in the Horn of Africa. Sci. Adv., $\mathbf{1}$, e1500682, https://doi.org/10.1126/sciadv.1500682.

Titchner, H. A., and N. A. Rayner, 2014: The Met Office Hadley Centre sea ice and sea surface temperature data set, version 2: 1. Sea ice concentrations. J. Geophys. Res. Atmos., 119, 2864 2889, https://doi.org/10.1002/2013JD020316.

Todd, M. C., and R. Washington, 2004: Climate variability in central equatorial Africa: Influence from the Atlantic sector. Geophys. Res. Lett., 31, L23202, https://doi.org/10.1029/2004GL020975.

Uccellini, L. W., and D. R. Johnson, 1979: The coupling of upper and lower tropospheric jet streaks and implications for the development of severe convective storms. Mon. Wea. Rev., 107, 682-703, https://doi.org/10.1175/1520-0493(1979)107<0682: TCOUAL $>2.0 . \mathrm{CO} ; 2$.
Ummenhofer, C. C., A. Sen Gupta, M. H. England, and C. J. C. Reason, 2009: Contributions of Indian Ocean sea surface temperatures to enhanced East African rainfall. J. Climate, 22, 993-1013, https://doi.org/10.1175/2008JCLI2493.1.

Van Der Ent, R. J., H. H. G. Savenije, B. Schaefli, and S. C. SteeleDunne, 2010: Origin and fate of atmospheric moisture over continents. Water Resour. Res., 46, W09525, https://doi.org/ 10.1029/2010WR009127.

Viste, E., D. Korecha, and A. Sorteberg, 2013: Recent drought and precipitation tendencies in Ethiopia. Theor. Appl. Climatol., 112, 535-551, https://doi.org/10.1007/s00704-012-0746-3.

Voldoire, A., and Coauthors, 2013: The CNRM-CM5.1 global climate model: Description and basic evaluation. Climate Dyn., 40, 2091-2121, https://doi.org/10.1007/s00382-011-1259-y.

Wang, C., L. Zhang, S.-K. Lee, L. Wu, and C. R. Mechoso, 2014: A global perspective on CMIP5 climate model biases. Nat. Climate Change, 4, 201-205, https://doi.org/10.1038/nclimate2118.

Washington, R., and Coauthors, 2006: African climate change: Taking the shorter route. Bull. Amer. Meteor. Soc., 87, 13551366, https://doi.org/10.1175/BAMS-87-10-1355.

- R. James, H. Pearce, W. M. Pokam, and W. Moufouma-Okia, 2013: Congo basin rainfall climatology: Can we believe the climate models? Philos. Trans. Roy. Soc. London, 368B, 20120296, https://doi.org/10.1098/rstb.2012.0296.

Watanabe, M., and Coauthors, 2010: Improved climate simulation by MIROC5: Mean states, variability, and climate sensitivity. J. Climate, 23, 6312-6335, https://oi.org/10.1175/ 2010JCLI3679.1.

Williams, A. P., and Coauthors, 2012: Recent summer precipitation trends in the greater Horn of Africa and the emerging role of Indian Ocean sea surface temperature. Climate Dyn., 39, 2307-2328, https://doi.org/10.1007/s00382-011-1222-y.

Williams, C. A., N. P. Hanan, J. C. Neff, R. J. Scholes, J. A. Berry, A. S. Denning, and D. F. Baker, 2007: Africa and the global carbon cycle. Carbon Balance Manag., 2, https://doi.org/ 10.1186/1750-0680-2-3.

Wu, T., and Coauthors, 2013: Global carbon budgets simulated by the Beijing Climate Center Climate System Model for the last century. J. Geophys. Res. Atmos., 118, 4326-4347, https://doi.org/ 10.1002/jgrd.50320.

Xie, P., and P. A. Arkin, 1997: Global precipitation: A 17-year monthly analysis based on gauge observations, satellite estimates, and numerical model outputs. Bull. Amer. Meteor. Soc., 78, 2539-2558, https://doi.org/10.1175/1520-0477(1997)078<2539: GPAYMA $>2.0 . \mathrm{CO} ; 2$.

Xu, Z., P. Chang, I. Richter, W. Kim, and G. Tang, 2014: Diagnosing southeast tropical Atlantic SST and ocean circulation biases in the CMIP5 ensemble. Climate Dyn., 43, 31233145, https://doi.org/10.1007/s00382-014-2247-9.

Yang, W., R. Seager, M. A. Cane, and B. Lyon, 2015: The rainfall annual cycle bias over East Africa in CMIP5 coupled climate models. J. Climate, 28, 9789-9802, https://doi.org/10.1175/ JCLI-D-15-0323.1.

Yukimoto, S., and Coauthors, 2012: A new global climate model of the Meteorological Research Institute: MRI-CGCM3Model description and basic performance. J. Meteor. Soc. Japan, 90A, 23-64, https://doi.org/10.2151/jmsj.2012-A02.

Zuidema, P., and Coauthors, 2016: Challenges and prospects for reducing coupled climate model SST biases in the eastern tropical Atlantic and Pacific Oceans: The U.S. CLIVAR eastern tropical oceans synthesis working group. Bull. Amer. Meteor. Soc., 97, 2305-2328, https://doi.org/10.1175/BAMS-D-15-00274.1. 